GEAP-10363

AEC RESEARCH AND

DEVELOPMENT REPORT

APRIL 1971

\title{
ZIRCALOY.CLAD $\mathrm{UO}_{2}$ FUEL ROD EVALUATION PROGRAM PROGRESS REPORT NO. 13 NOVEMBER 1970-MARCH 1971
}

COMPILED BY

F.H. MEGERTH

U.S. ATOMIC ENERGY COMMISSION

CONTRACT AT(04-3)-189

PROJECT AGREEMENT 41

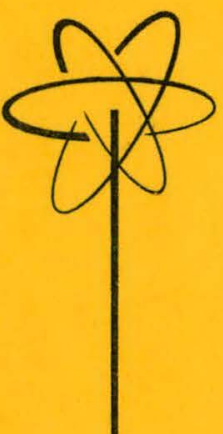




\section{DISCLAIMER}

This report was prepared as an account of work sponsored by an agency of the United States Government. Neither the United States Government nor any agency Thereof, nor any of their employees, makes any warranty, express or implied, or assumes any legal liability or responsibility for the accuracy, completeness, or usefulness of any information, apparatus, product, or process disclosed, or represents that its use would not infringe privately owned rights. Reference herein to any specific commercial product, process, or service by trade name, trademark, manufacturer, or otherwise does not necessarily constitute or imply its endorsement, recommendation, or favoring by the United States Government or any agency thereof. The views and opinions of authors expressed herein do not necessarily state or reflect those of the United States Government or any agency thereof. 


\section{DISCLAIMER}

Portions of this document may be illegible in electronic image products. Images are produced from the best available original document. 


\section{ZIRCALOY-CLAD UO, FUEL ROD EVALUATION PROGRAM}

Progress Report No. 13 November 1970-March 1971

Compiled by

F.H. Megerth

Approved:

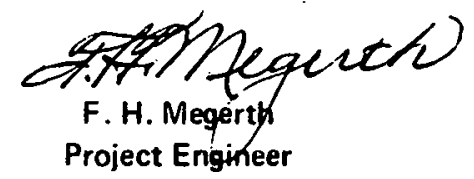

Approved:

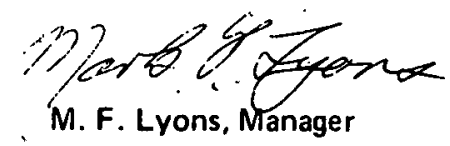

Fuel Development-Water Reactors
Prepared for the

U. S. Atomic Energy Commission

Contract AT(04-3)-189

Project Agreement 41

This report was prepared as an account of work sponsored by the United States Governmenc. Neitlier the United States nor the United States Atomic Energy Commission, nor any. of their employees, nor any of their contractors, subcontractors, or their employees, makes any warranty, express or implied, or assumes any legal liability or responsibility for the accuracy, completeness or usefulness of any information, apparatus, product or process disclosed, or represents that its use would not infringe privately owned rights. 


\section{NOTICE}

This report was prepared as an account of work sponsored by the United States Government. Neither the United States nor the United States Atomic Energy Commission, nor any of their employees, nor any of their contractors, subcontractors, or their employees, makes any warranty, express or implied, or assumes any legal liability. or responsibility for the accuracy, completeness or usefulness of any information, apparatus, product or process disclosed, or represents that its use would not infringe privately owned rights. 


\section{TABLE OF CONTENTS}

1. Introduction . . . . . . . . . . . . . . . . . . . . . . 1

2. Summary . . . . . . . . . . . . . . . . . . . . . . 2

3. Examinations and Analyses of Fuel Rods . . . . . . . . . . . . . . . . . . . . . 2

3.1 Fuel Rod Performance Evaluation . . . . . . . . . . . . . . . . . . . . 2

3.2 Fuel Burnup and Isotopic Composition Analyses . . . . . . . . . . . . . . . . . . . 7

4. Illustrations . . . . . . . . . . . . . . . . . . . . . . . . . 11

References. . . . . . . . . . . . . . . . . . . . . . . . . . 22

Acknowledgment . . . . . . . . . . . . . . . . . . . . . 22

Distribution . . . . . . . . . . . . . . . . . . . . . . . 23 


\section{LIST OF ILLUSTRATIONS}

Figure

Title

1 Subassembly Spacer Spring Marking on Rod B50 . . . . . . . . . . . . . . . . . . . . . . . 11

2 Region of Rod B56 Where Crud Has Spalled from Surface . . . . . . . . . . . . . . . 12

3 Portion of Rod B56 Cladding Showing Thick Crud and External $\mathrm{ZrO}_{2}$ (Specimen No. A624) . . . . 12

4 SA-1 Cladding Samples After Burst Testing . . . . . . . . . . . . . . . . . . . . 13

5 Burst Samples Tested at Room Temperature: Unirradiated (above); Irradiated Sample A42C-1 (right) Which Was Held at $454^{\circ}\left(850^{\circ}\right)$ for $1 / 2$ hour Before Testing . . . . . . . . . . . . . . . 14

6 Burst Samples Tested at $\sim 343^{\circ} \mathrm{C}\left(650^{\circ} \mathrm{F}\right)$ : Unirradiated Sample No. 3 (left); Irradiated Sample A47D-2 (right) . . . . . . . . . . . . . . . . . . . . . 15

7 Burst Samples Tested at $\sim 399^{\circ} \mathrm{C}\left(750^{\circ} \mathrm{F}\right)$ : Unirradiated Sample No. 6 (left); Irradiated Sample B98C-1 (right). . . . . . . . . . . . . . . . . . . . . . . . . . . . 16

8. Burst Samples Tested at $\sim 454^{\circ} \mathrm{C}\left(850^{\circ} \mathrm{F}\right)$ : Unirradiated Sample No. 9 (left, top); Irradiated Samples B50A-2 (left, bottom) and B96C-2 (right) . . . . . . . . . . . . . . . . . . . . . 17

9 Values of $\left(D_{f}-D_{i}\right) / D_{i} \times 100$ at Various Points Along Samples Tested at a Nominal Temperature of $343^{\circ} \mathrm{C}\left(650^{\circ} \mathrm{F}\right)$. (Two determinations 90 degrees apart were made at each axial location indicated.)

10 Values of $\left(D_{f}-D_{i}\right) / D_{i} \times 100$ at Various Points Along Samples Tested at a Nominal Temperature of $399^{\circ} \mathrm{C}\left(750^{\circ} \mathrm{F}\right)$

11 Values of $\left(D_{f}-D_{i}\right) / D_{i} \times 100$ at various Points along Samples Tested at a Nominal Temperature of $454^{\circ} \mathrm{C}\left(850^{\circ} \mathrm{F}\right)$

12 Location of Burnup and Isotopic Composition Samples from Rods A37 and B62 in Terms of Distance from the Bottom of the Reactor Active Fuel Zone .

\section{LIST OF TABLES}

1 Thickness of Crud and $\mathrm{ZrO}_{2}$ on the Cladding of Transverse Metallography Specimens . . . . . . 3

2 Analyses of Gases Evolved from Fuel Rod Cladding Samples . . . . . . . . . . . . . . . . . . . 5

3 Burst Tests on SA-1 Cladding Samples . . . . . . . . . . . . . . . . . . . . . . . . . . . . . . . 7

4 Uranium and Plutonium Isotopic Compositions . . . . . . . . . . . . . . . . . . . . . . . . . . 8

5 Distribution of Fissions Among Uranium and Plutonium Isotopes . . . . . . . . . . . . . . . . . . . . . 9 


\section{INTRODUCTION}

At the time of the final shutdown of the Vallecitos Boiling Water Reactor (VBWR) and the termination of the AEC Fuel Cycle Program (Contract AT(04-3)-189, Project Agreement 11), the leading Zircaloy-2-clad $\mathrm{UO}_{2}$ fuel rods of the program's Type $J$ basic assemblies had attained rod average exposures as high as $3 \times 10^{20}$ fissions $/ \mathrm{cm}^{3}$ $(10,000 \mathrm{MWd} / \mathrm{t} U)$.

To demonstrate at the earliest possible time the capability of Zircaloy-clad fuel to achieve average burnups of at least $6 \times 10^{20}$ fissions $/ \mathrm{cm}^{3}(20,000 \mathrm{MWd} / \mathrm{t} \mathrm{U})$ and to take advantage of the available lead time in achieving these buinup targets, 98 of the higher exposure Fuel Cycle Program rods were incorporated in a special assembly designated as SA-1 and inserted in the Dresden Reactor Unit No. 1 for additional irradiation. The assembly consisted of two 7-by-7 subassemblies, stacked one on top of the other in a channel of standard dimensions for the Dresden reactor.

Assembly SA-1 was operated continuously from June 1964 to September 1969, with the exception of reactor shutdowns for refueling and maintenance.

To investigate in detail the performance of the SA-1 fuel rods and to determine the isotopic composition of the highly exposed fuel, a two-phase program of destructive examination and analysis was drawn up. For the initial phase of the program, ten rods were removed from the assembly in January 1967, atter 1200 days of VBWR and Dresden operation, and were shipped to the Vallecitos Nuclear Center. The remaining rods operated a total of 1850 days. The two 44-rod subassemblies were shipped to VNC in March 1970, where the final phase of the program is now in progress.

Prior reports to the Atomic Energy Commission under Project Agreement 41 comprise the following:

a. "Zircaloy-Clad $\mathrm{UO}_{2}$ Fuel Rod Evaluation Program, Quarterly Progress Report No. 1, November 1967-January 1968," March 1968 (GEAP-5598).

b. 'Zircaloy-Clad UO $\mathrm{O}_{2}$ Fuel Rod Evaluation Program, Quarterly Progress Report No. 2, February 1968-April 1968," May 1968 (GEAP.6631).

c. "Zircaloy:Clad $\mathrm{UO}_{2}$ Fuel Rod Evaluation Program, Quarterly Progress Report No. 3, May 1968-July 1968," August 1968 (GEAP.5667).

d. "Zircaloy-Clad $\mathrm{UO}_{2}$ Fuel Rod Evaluation Program, Quarterly Progress Report No. 4, August 1968-October 1968," November 1968 (GEAP-5702).

e. 'Zircaloy-Clad $\mathrm{UO}_{2}$ Fuel Rod Evaluation Program Quarterly Progress' Report No. 5, November 1968-January 1969," February 1969 (GEAP-5746).

f. "Zircaloy-Clad $\mathrm{UO}_{2}$ Fuel Rod Evaluation Program, Quarterly Progress Report Nos. 6 and 7, February-July 1969," August 1969 (GEAP-10079).

g. "Zircaloy-Clad $\mathrm{UO}_{2}$ Fuel Rod Evaluation Program, Quarterly Progress Report No. 8, August-October 1969," November 1969 (GEAP-10121).

h. "Zircaloy-Clad $\mathrm{UO}_{2}$ Fuel Rod Evaluation Program, Quarterly Progress Report No. 9, November 1969-January 1970," February 1970 (GEAP-10160).

i. "Zircaloy-Clạd $\mathrm{UO}_{2}$ Fuel Rod Evaluation Program, Quarterly Progress Report No. 10, February-April 1970," May 1970 (GEAP-10204).

j. "Zircaloy-Clad $\mathrm{UO}_{2}$ Fuel Rod Evaluation Program, Quarterly Progress Report No. 11, May-July 1970," August 1970 (GEAP.10217).

k. "Zircaloy-Clad $\mathrm{UO}_{2}$ Fuel Rod Evaluation Program, Quarterly Progress Report No. 12, August-October 1970," November 1970 (GEAP-10287). 


\section{SUMMARY}

Earlier in the examinations, a neutron radiograph of one of the fuel rods showed a small region in the cladding that was believed to be possibly defective. Recent metallographic examination of this region, however, failed to reveal any defect. On another rod, a relative increase in cladding corrosion was noted near a prominent spacer spring contact mark. The external $\mathrm{ZrO}_{2}$ layer was continuous and approximately $100 \mu(0.004$ in.) thick in the contact area. The corrosion layer around the rest of the rod section typically consisted of a $\sim 15 \mu$. thick film with numerous intermittent oxide patches 60 to $90 \mu$ thick. Metallographic examination of a section of a rod that showed considerable crud spalling indicated that the circumferential-average crud thickness was $28 \mu(0.0011$ in.), which amount was the maximum measured on any specimen. Although the external $\mathrm{ZrO}_{2}$ on this specimen was above average in thickness, a few other specimens showed thicker oxide layers.

Cladding samples from selected fuel rods were analyzed for total hydrogen and other gaseous constituents by vacuum hot extraction followed by gas chromatography. The total volumes of gas evolved from the samples ranged from approximately 700 to $\mathbf{2 2 0 0}$ microliters per gram of cladding. The analyses showed total hydrogen contents of $\mathbf{7 2}$ to $96 \%$, carbon monoxide contents of $\bar{j}$ to $24 \%$, and smaller amounts of carbon dioxide, nitrogen, oxygen, and methane. In terms of parts per million, the total hydrogen contents ranged from 46 to 143 ppm. The maximum absorption of corrosion-generated hydrogen was about $4 \%$.

Samples of irradiated fuel rod cladding that were burst tested at room temperature and at $343^{\circ} \mathrm{C}\left(650^{\circ} \mathrm{F}\right), 399^{\circ} \mathrm{C}$ $\left(750^{\circ} \mathrm{F}\right)$, and $454^{\circ} \mathrm{C}\left(850^{\circ} \mathrm{F}\right)$ showed respective hoop stresses at rupture of approximately $8000 \mathrm{~kg} / \mathrm{cm}^{2}(114 \mathrm{kpsi})$ $5100 \mathrm{~kg} / \mathrm{cm}^{2}(72 \mathrm{kpsi}), 4900 \mathrm{~kg} / \mathrm{cm}^{2}(69 \mathrm{kpsi})$, and $4400 \mathrm{~kg} / \mathrm{cm}^{2}$ (62 kpsi). Irradiation increased the stress.values 1400 to $1800 \mathrm{~kg} / \mathrm{cm}^{2}$ (19 to $25 \mathrm{kpsi}$ ). Strain to fracture values ranged from 2 to $8 \%$ among the irradiated samples, and did not show any clear temperature dependence between $343^{\circ} \mathrm{C}$ and $454^{\circ} \mathrm{C}$.

Several full cross-section fuel samples were analyzed for burnup by measuring the neodymium isotopes, and for uranium and plutonium isotopic composition. Most of the samples were taken from the peak exposure locations of the rods and ranged from $8.4 \times 10^{20}$ to $10.4 \times 10^{20}$ fissions $/ \mathrm{cm}^{3}(30,800$ to $37,900 \mathrm{MWd} / \mathrm{tU})$ in burnup. The ratios of peak burnup to average burnup, obtained from gamma scans, were applied to determine the rod-average burnups. These values ranged from $7.6 \times 10^{20}$ to $9.3 \times 10^{20}$ fissions $/ \mathrm{cm}^{3}(27,900$ to $33,900 \mathrm{MWd} / \mathrm{tU})$. Samples also were taken from near the ends of the fuel columns of two high-exposure rods and analyzed for burnup and isotopic composition.

\section{EXAMINATIONS AND ANALYSES OF FUEL RODS}

\subsection{FUEL ROD PERFORMANCE EVALUATION}

\subsubsection{Metallographic Examination of Rod Sections (D: L. Orton, R. E. Smith)}

Three transverse rod section metallography specimens were examined in addition to those discussed in the preceding progress report. ${ }^{\prime}$ One of the current specimens (No. A626 from rod A9) was prepared, to examine a possibly defective area in the cladding of the rod. The area showed on a neutron radiograph print as a $\sim 0.1-\mathrm{cm}(\sim 0.04 \mathrm{in}$.$) -long$ spot slightly darker than the surrounding background. Metallographic examination failed to reveal any reason for the spot. Nothing unusual was noted during the earlier visual examinations of the rod surface or on the diameter profile traces, and analyses of the contained gases indicated that the rod was sound.

During the visual examinations of the fuel rods, markings frequently were noted near points of contact with the SA-1 subassembly spacer springs. ${ }^{2.3}$ The most prominent of these are shown by corner rod B50. The surface appearance of this contact area can be seen in Figure 1. "Specimen No. A625 was prepared so that the area could be viewed in cross section. In general, the external corrosion layer around the specimen consisted of a $\sim 15 \mu$ thick film with numerous intermittent oxide patches 60 to $90 \mu$ thick. A relative increase in corrosion was noted in the vicinity of the prominent contact area in octant 3 and part of octant 2 (see Table 1).In this region the external $\mathrm{ZrO}_{2}$ layer was continuous and 90 to $100 \mu(0.0035$ to 0.004 in.) thick.

*All illustrations are included in Section 4. 
THICKNESS OF CRUD AND $\mathrm{ZrO}_{2}$ ON THE CLADDING OF TRANSVERSE METALLOGRAPHY SPECIMENS

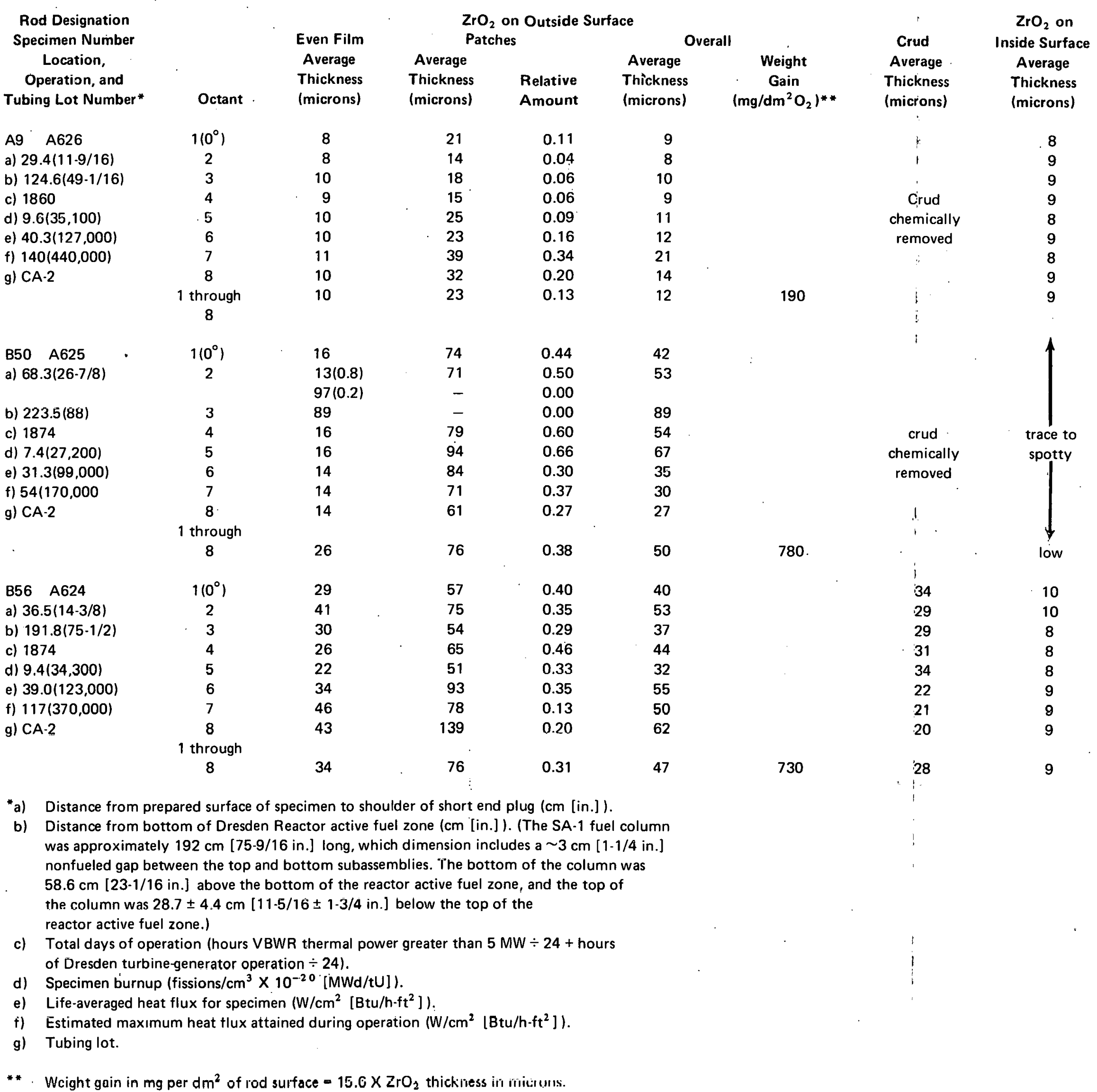


Similar areas on rod $\mathrm{B} 70$ were examined during the initial phase of the program. The $\mathrm{ZrO}_{2}$ ranged from 70 to $100 \mu$ in thickness r.ear the most prominent contact area on the earlier specimen. ${ }^{4}$ Thus, although rod B50 operated 1500 days in Assembly SA.1, compared with 840 days for rod B70, the corrosion shown by rod B50 in the spring. contact region was not much greater than that shown by rod $B 70$.

The prepared surface of specimen No. A625 included a second spring-rod contact area 90 degrees from the one just discussed. This second region showed some enhancement of corrosion, but not to the degree shown by the first contact area.

Specimen No. A624 was taken from a corner rod (B56) which appeared to have an unusually thick crud layer. The crud had spalled down to a continuous white $\mathrm{ZrO}_{2}$ surface at several locations, one of which is shown in Figure 2. A portion of the crud and $\mathrm{ZrO}_{2}$ layers are shown in cross-sectional view in Figure 3. The average thickness of crud on this specimen was $28 \mu$ (0.0011 in.), which amount was the maximum measured on any specimen and approximately twice the average thickness measured on the specimens taken as a group. The weight gain shown by specimen No. A624 was $230 \mathrm{mg} / \mathrm{dm}^{2}$ greater than the average for all 16 specimens, but it was still lower than the weight gains shown by 4 specimens.

\subsubsection{Cladding Hydrogen Analysis (D. E. Rey)}

Six cladding samples from four fuel rods were analyzed for total hydrogen and other gaseous constituents by vacuum hot extraction, followed by gas chromatography. The details of the procedures used in this work were presented in an earlier progress report. ${ }^{3}$ The results of the current analyses are given in Table 2. The total volumes of gas evolved from the samples ranged from approximately 700 to $\mathbf{2 2 0 0}$ microliters per gram of cladding. The analyses showed total hydrogen contents of 72 to $96 \%$, carbon monoxide contents of 5 to $24 \%$, and carbon dioxide contents of 0.3 to $2 \%$. The samples also contained up to $0.6 \%$ nitrogen and oxygen, and up to $0.05 \%$ methane. The maximum total gas content and \% $\mathrm{CO}$ value are about twice the corresponding maximums determined on samples from rods that were removed from SA-1 after 1200 days of VBWR and Dresden operation. ${ }^{3}$ However, the $\%$ CO values are no greater than some of those obtained in the analyses of samples from rods that saw only VBWR operation under the Fuel Cycle Program. ${ }^{5}$ In terms of parts per million, the total hydrogen contents of the current set of samples ranged from 46 to $143 \mathrm{ppm}$. The maximum content of any of the earlier samples was $89 \mathrm{ppm}$. The maximum absorption of corrosion-generated hydrogen was still only about $4 \%$.

\subsubsection{Burst Testing of Cladding Samples (G. P. Ferguson)}

\subsubsection{Procedure}

Samples of cladding that had been exposed to estimated fast fluences of $4 \times 10^{21}$ to $5 \times 10^{21}$ nvt $(E>1 \mathrm{MeV})$ were obtained for burst testing by sectioning out $20-\mathrm{cm}(8 \mathrm{in}$.) - lengths from selected fuel rods. All of the irradiated cladding samples came from tubing lot CA-2. One-half of the SA-1 rods were clad with tubing from this lot; hence it was the most representative and afforded the best selection of samples. For comparison, unirradiated control samples were cut from Type $J$ Zircaloy-2 Fuel Cycle Program tubing that had been autoclaved. All of the control samples came from tubing lot CA-3; unfortunately, only tubing from this lot was in sufficient supply to prepare the required number. The unirradiated samples were tested in the hot cell according to the same procedure used on the irradiated samples.

Before an irradiated sample was tested, the crud and some of the external $\mathrm{ZrO}_{2}$ were removed from $\sim 2 \mathrm{~cm}$ $(\sim 3 / 4$ in.) of each end with emery cloth. Most of the fuel was left intact within the cladding; approximately 0.6 to $1.0 \mathrm{~cm}(1 / 4$ to $3 / 8 \mathrm{in}$.) was removed from one end so that wall thickness measurements could be made with a micrometer. The outside diameter of each sample was measured with a micrometer at the middle and at $5.1 \mathrm{~cm}(2 \mathrm{in}$.) from each end in two orientations 90 degrees apart. One end of the sample was sealed with a stainless steel Swagelok cap type tube fitting. The other end was connected to a $1400 \mathrm{~kg} / \mathrm{cm}^{2}(20,000 \mathrm{psi})$ air-driven gas booster through $0.6 \mathrm{~cm}(1 / 4 \mathrm{in}$.) $0 . d$. by $0.21 \mathrm{~cm}(0.083 \mathrm{in}$.) wall high-pressure tubing which was joined to the sample by means of another stainiless steel Swagelok tube fitting. The length of sample between the fittings was approximately $16 \mathrm{~cm}$ (6-1/4 in.). The sample was placed in the center of a $3.8 \mathrm{~cm}(1-1 / 2 \mathrm{in.})$ i.d. by $0.6 \mathrm{~cm} \mathrm{(1/4} \mathrm{in.)} \mathrm{wall} \mathrm{by} 25 \mathrm{~cm}(10 \mathrm{in}$.) long steel shroud tube which was capped at each end. 
ANAL YSES OF GASES EVOLVEDle 2

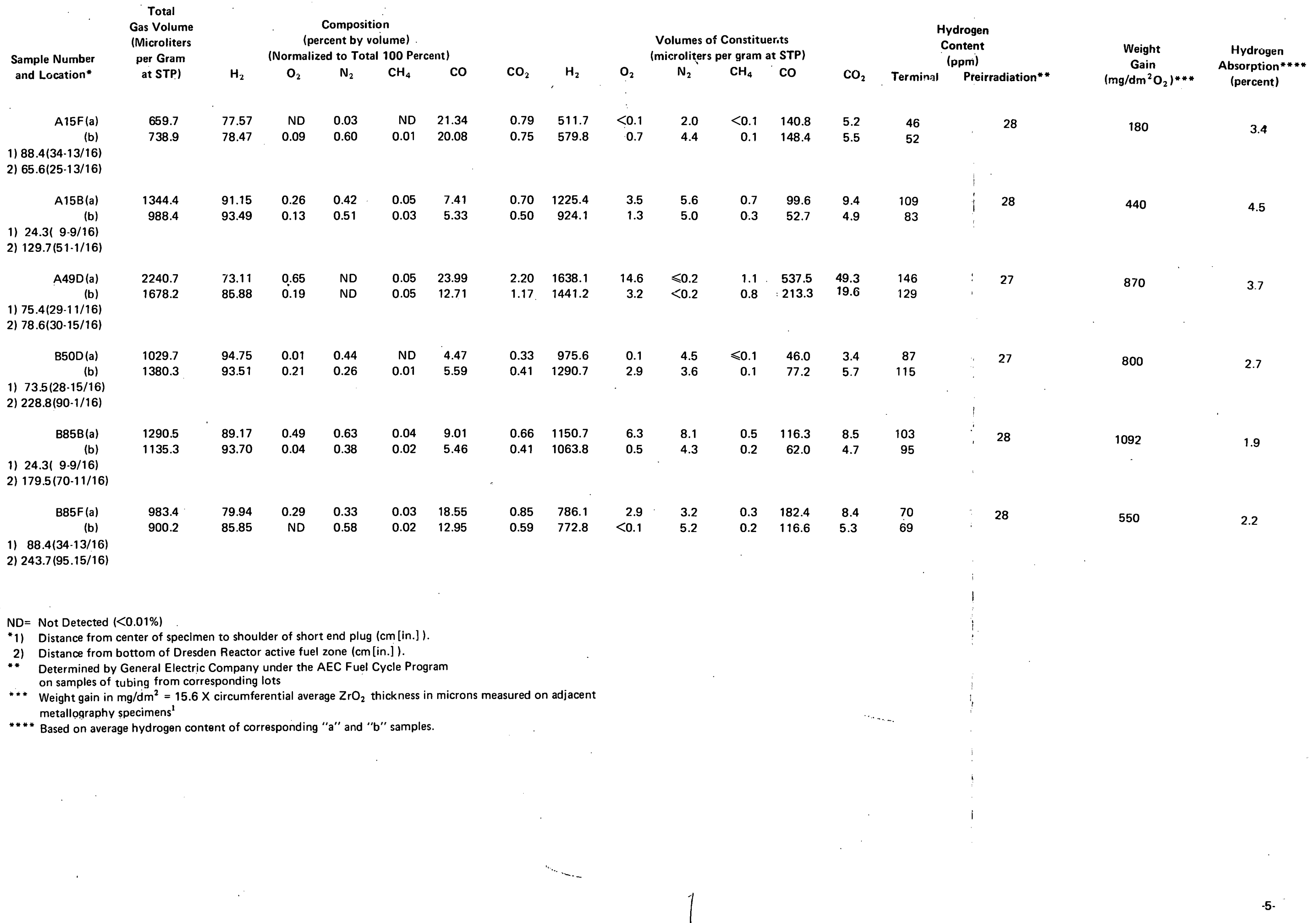


The sample then was pressurized to failure with argon at a rate of $53 \pm 21 \mathrm{~kg} / \mathrm{cm}^{2} \cdot \min (750 \pm 300 \mathrm{psi} / \mathrm{min}$.$) .$ (However, the rate at the time of rupture was unintentionally increased to $320 \mathrm{~kg} / \mathrm{cm}^{2}-\min [4600 \mathrm{psi} / \mathrm{min}$ ] in the case of sample B98C-1, and to $89 \mathrm{~kg} / \mathrm{cm}^{2}-\mathrm{min}[1260 \mathrm{psi} / \mathrm{min}]$ in the case of the unirradiated $454^{\circ} \mathrm{C}\left[850^{\circ} \mathrm{F}\right.$ ] control sample.) The pressure was measured by both a Bourdon tube gage and a transducer. The transducer output was fed into a strain gage signal conditioner, and the readout was continuously recorded in terms of pressure on a strip chart recorder.

Tests were performed at nominal temperatures of $343^{\circ} \mathrm{C}\left(650^{\circ} \mathrm{F}\right), 399^{\circ} \mathrm{C}\left(750^{\circ} \mathrm{F}\right)$, and $454^{\circ} \mathrm{C}\left(850^{\circ} \mathrm{F}\right)$, in addition to room temperature. To carry out the high-temperature tests, the shrouded sample was placed in an electric resistance tube furnace. The sample temperature was measured by means of three chromel-alumel thermocouples located at the middle and at $5.1 \mathrm{~cm}(2 \mathrm{in.})$ from each end of the sample. The middle thermocouple was connected to a saturable reactor temperature controller. The sample was brought to the test temperature and held there $1 / 2 \mathrm{hour}$. It was then pressurized to failure. The temperature at the middle of the sample was somewhat higher than at the other locations measured. The three temperature readings were generally within $5-1 / 2^{\circ} \mathrm{C}$ to $8-1 / 2^{\circ} \mathrm{C}\left(10^{\circ} \mathrm{F}\right.$ to $\left.15^{\circ} \mathrm{F}\right)$ of each other throughout the test. In the case of the unirradiated $454^{\circ} \mathrm{C}$ control sample, the temperature at one end was $\sim 17^{\circ} \mathrm{C}$ $\left(30^{\circ} \mathrm{F}\right)$ lower than at the middle.

The diameter of a tested sample was measured with the micrometer at locations just outside of the burst region and, in most cases, at locations somewhat removed from the burst region as well. The measurements were made in two orientations, 90 degrees apart.

In addition to the foregoing measurements, the distance around a tested sample from one edge of the primary (longitudinal) fracture to the other was measured by using strips of $0.0025-\mathrm{cm}(0.001 \mathrm{in}$.) -thick stainless steel foil, $0.16 \mathrm{~cm}(1 / 16 \mathrm{in.})$ to $0.32 \mathrm{~cm}(1 / 8 \mathrm{in}$.$) wide by approximately 25 \mathrm{~cm}(10 \mathrm{in.})$ long. While the sample was held in a horizontal position, one of these foil strips-with small lead weights attached to each end-was wrapped around the fracture region at the location of apparent maximum circumferential elongation. Pulling the strip taut about the sampla resulted in a crimping of the strip at the edges of the fracture. The distance between the crimp marks $\left(C_{f}\right)$ was then measured out of cell by means of a scale and magnifying glass. The measured distances between crimp marks on duplicate foil strips were found to be within 0.025 to $0.05 \mathrm{~cm}(0.01$ to $0.02 \mathrm{in}$.) of each other on each of the irradiated samples and on the room-temperature control sample. Reproducibility was poorer on the high-temperature control samples due to the irregular nature of the fractures shown by these samples.

\subsubsection{Results}

The control and irradiated samples are shown, after testing, in Figures 4 through 8, and the values of burst pressure, hoop stress at rupture, and percent strain to fracture are listed in Table 3. The $\triangle D / D_{i}$ values in the table were calculated frum selected post-test diameter measurements made near the burst regions and the corresponding pre-test measurements. The locations at which these values were determined for the high test temperature samples are indicated in Figures 9 through 11. $\Delta \mathrm{D} / \mathrm{D}_{\mathrm{i}}$ values determined at locations away from the burst regions also are designated. The circumferential elongation values $\left(C_{f}-C_{i}\right) / C_{i} \times 100$ in Table 3 were calculated from measurements made on the foil strips and the corresponding pre-test diameter measurements.

The average stresses at rupture for irradiated samples tested at room temperature and at nominal temperatures of $343^{\circ} \mathrm{C}, 399^{\circ} \mathrm{C}$, and $454^{\circ} \mathrm{C}$, were $8000 \mathrm{~kg} / \mathrm{cm}^{2},(114 \mathrm{kpsi}), 5100 \mathrm{~kg} / \mathrm{cm}^{2}(72 \mathrm{kpsi}), 4900 \mathrm{~kg} / \mathrm{cm}^{2}(69 \mathrm{kpsi})$, and $4400 \mathrm{~kg} / \mathrm{cm}^{2}(62 \mathrm{kpsi})$, respectively. Based on these average values for each pair of irradiated samples, the largest difference between irradiated and unirradiated control samples was shown in the $343^{\circ} \mathrm{C}$ tests $\left(1800 \mathrm{~kg} / \mathrm{cm}^{2}\right.$ or $\left.25 \mathrm{kpsi}\right)$ and the smallest difference was shown in the room temperature and $454^{\circ} \mathrm{C}$ tests $\left(1400 \mathrm{~kg} / \mathrm{cm}^{2}\right.$ or $\left.19 \mathrm{kpsi}\right)$.

It should be pointed out that while one of the room temperature samples was tested in a normal manner, the second was held at the highest test temperature investigated in the current series (i.e., $454^{\circ} \mathrm{C}$ ) for the standard holding time before being pressurized at room temperature. Although the stress to rupture shown by the second sample was somewhat lower than that of the first, the difference in values probably was no greater than one might expect to obtain between two comparable non-heat-treated samples. 
Table 3

BURST TESTS ON.SA-1 CLADDING SAMPLES

\begin{tabular}{|c|c|c|c|c|c|}
\hline \multirow[b]{2}{*}{$\begin{array}{c}\text { Sample } \\
\text { Number* }\end{array}$} & \multirow[b]{2}{*}{$\begin{array}{c}\text { Test } \\
\text { Temperature } \\
{ }^{\circ} \mathrm{C}\left({ }^{\circ} \mathrm{F}\right)\end{array}$} & \multirow[b]{2}{*}{$\begin{array}{l}\text { Burst Pressure } \\
\mathrm{kg} / \mathrm{cm}^{2} \text { (kpsi) }\end{array}$} & \multirow[b]{2}{*}{$\begin{array}{l}\text { Hoop Stress } \\
\mathrm{kg} / \mathrm{cm}^{2} \text { (kpsi) }\end{array}$} & \multicolumn{2}{|c|}{$\begin{array}{c}\text { Strain to Fracture } \\
\text { Percent }\end{array}$} \\
\hline & & & & $\frac{D_{f}-D_{i}}{D_{i}} \times 100$ & $\begin{array}{c}\text { Circumferential } \\
\text { Elongation }\end{array}$ \\
\hline Unirradiated (0) & Room & $716(10.19)$ & $6650(94.6)$ & 9 & 8 \\
\hline B98A-2 (1) & Room & $792(11.27)$ & $8320(118.4)$ & - & 8 \\
\hline A42C-1 (2) & Room** & $828(11.77)$ & $7660(109.0)$ & - & 6 \\
\hline Unirradiated (3) & $343(650)$ & $356(5.07)$ & $3330(47.3)$ & 27 & $\geqslant 30$ \\
\hline B96A-2 (4) & $348(659)$ & $564(8.02)$ & $4980(70.8)$ & 4 & 3 \\
\hline A47D-2 (5) & $348(659)$ & $586(8.34)$ & $5200(74.0)$ & 8 & 7 \\
\hline Unirradiated (6) & $403(757)$ & $338(4.81)$ & $3150(44.8)$ & 16 & $\geqslant 12$ \\
\hline B96C.1 (7) & $403(758)$ & $533(7.58)$ & $4960(70.6)$ & $3-4$ & 5 \\
\hline B98C-1 (8) & $393(740)$ & $532(7.56)$ & $4770(67.8)$ & 4 & 5 \\
\hline Unirradiated (9) & $454(850)$ & $315(4.48)$ & $3010(42.8)$ & 23 & $\geqslant 16$ \\
\hline B96C-2 (11) & $454(850)$ & $488(6.94)$ & $4490(63.8)$ & $2 \cdot 4$ & 4 \\
\hline$B 50 A \cdot 2(13)$ & 459 (859) & $478(6.80)$ & $4270(60.7)$ & 6 & 6 \\
\hline
\end{tabular}

Most of the strain to fracture values shown by the unirradiated high test temperature samples were considerably greater than those shown by the room temperature test sample. However, irradiation markedly decreased the strains to fracture among the high temperature samples; it showed a comparatively small effect at room temperature. The percent strain to fracture did not show any clear temperature dependence between $343^{\circ} \mathrm{C}$ and $454^{\circ} \mathrm{C}$.

It is of interest to note in Figures 9 through 11 that diametral expansions of 2 to $7 \%$ occurred at locations removed from the burst regions on the various irradiated high test temperature samples.

\subsection{FUEL BURNUP AND ISOTOPIC COMPOSITION ANALYSES}

(C. P. Ruiz, Technical Director; J. P. Peterson, F. R. Smith)

Burnup analyses, and uranium and plutonium isotopic composition analyses, were completed on 24 full cross-sectional fuel samples from 16 rods that had been selected from both subassemblies A-1 (bottom) and B-1 (top). The results are given in Table 4 . The burnup values listed were determined by measuring the neodymium isotopes.

Most of the samples analyzed were taken from the peak exposure locations of the rods (i.e., 25 to $30 \mathrm{~cm}$ [ 10 to $12 \mathrm{in.]}$ above or below the middle of the assembly) and ranged from $8.4 \times 10^{20}$ to $10.4 \times 10^{20}$ fissions $/ \mathrm{cm}^{3}(30,800$ to $37,900 \mathrm{MWd} / \mathrm{tU})$. Samples from near the ends of the fuel columns of high exposure rods A37 and B62 also were analyzed. The axial locations of these samples are indicated in Figurc 12.

The distribution of fissions among U-235, Pu-239, Pu-241, and U-238 are given for the different samples in Table 5 .

The average burnups for the 16 rods ranged from $7.6 \times 10^{20}$ to $9.3 \times 10^{20}$ fissions $/ \mathrm{cm}^{3} 127,900$ to $33,900 \mathrm{MWd} / \mathrm{tU}$ ). These values were obtained by applying the $\mathrm{Cs} .137$ gamma scan results to the sample burnup data. The peak-to-average burnup ratios ranged from 1.06 to 1.11 among the "A" rods and from 1.14 to 1.17 among the " $B$ " rods. $^{3}$ 
Table 4

SAMPLE BURNUPS AND URANIUM AND PLUTONIUM ISOTOPIC COMPOSITIONS

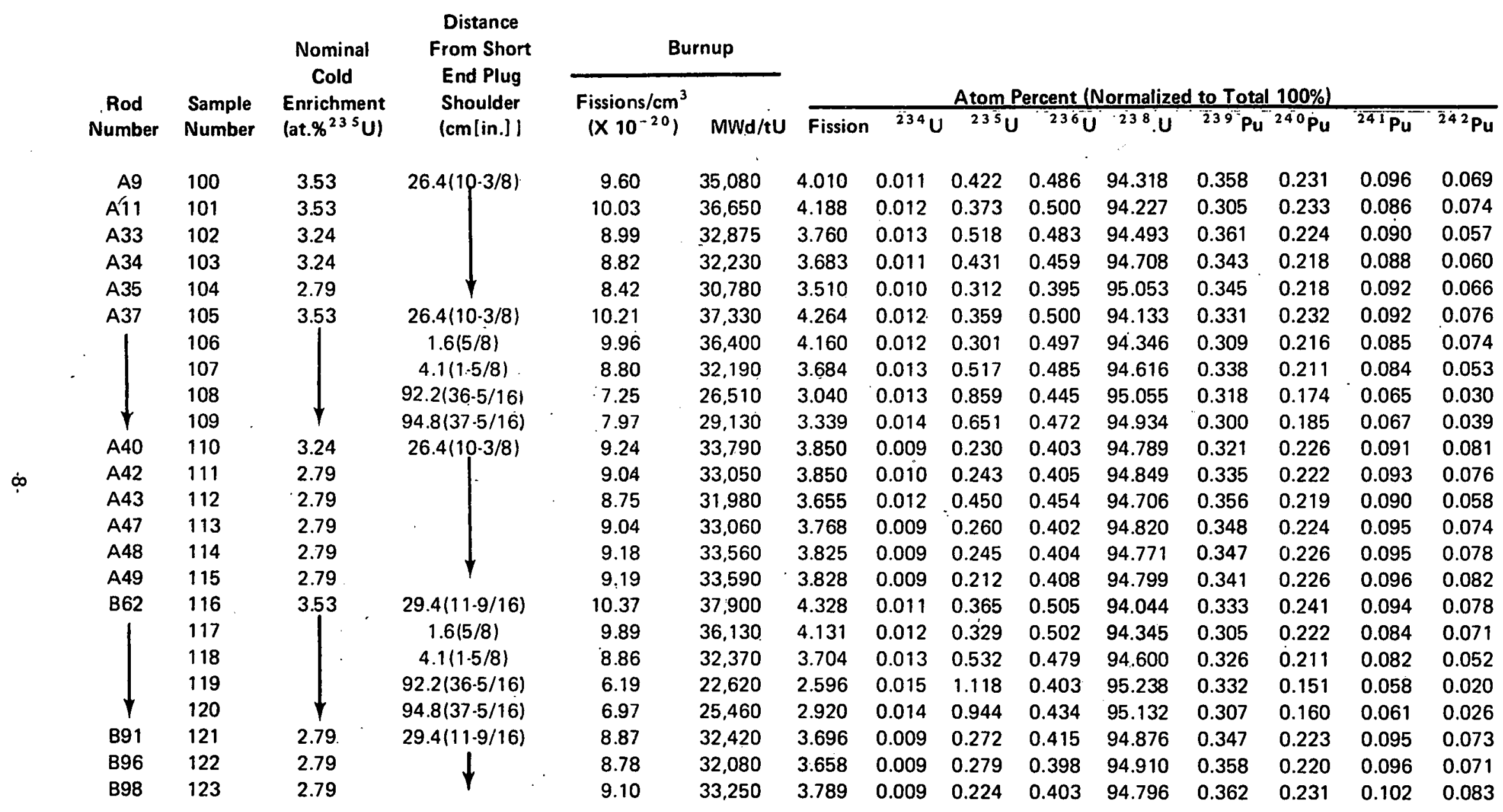


Table 5

DISTRIBUTION OF FISSIONS

AMONG URANIUM AVD PLUTONIUM ISOTOPES

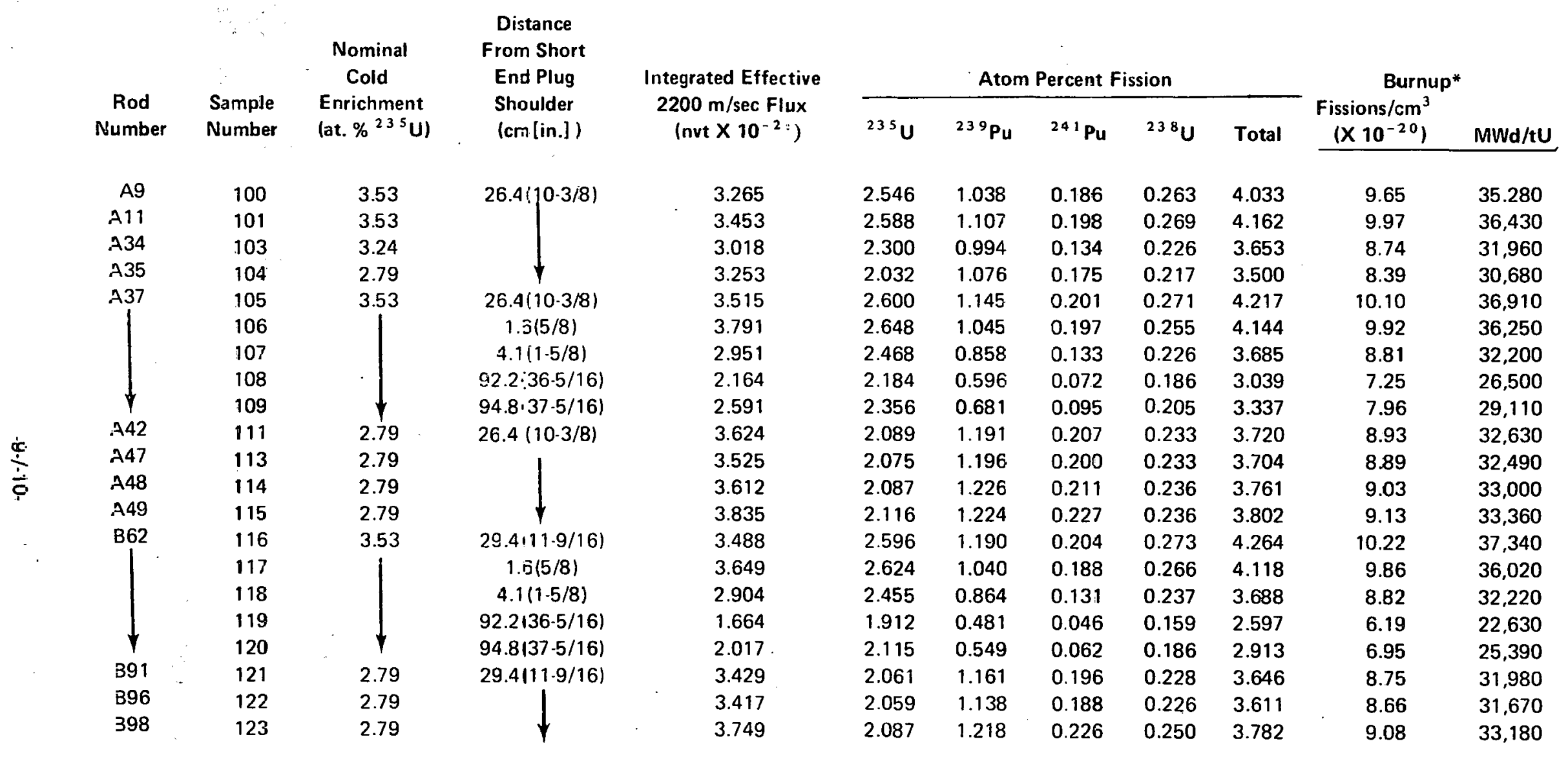

* from heavy element data 


\section{ILLUSTRATIONS}

This section cuntains Figures 1 through 12, as referenced in the preceding text.

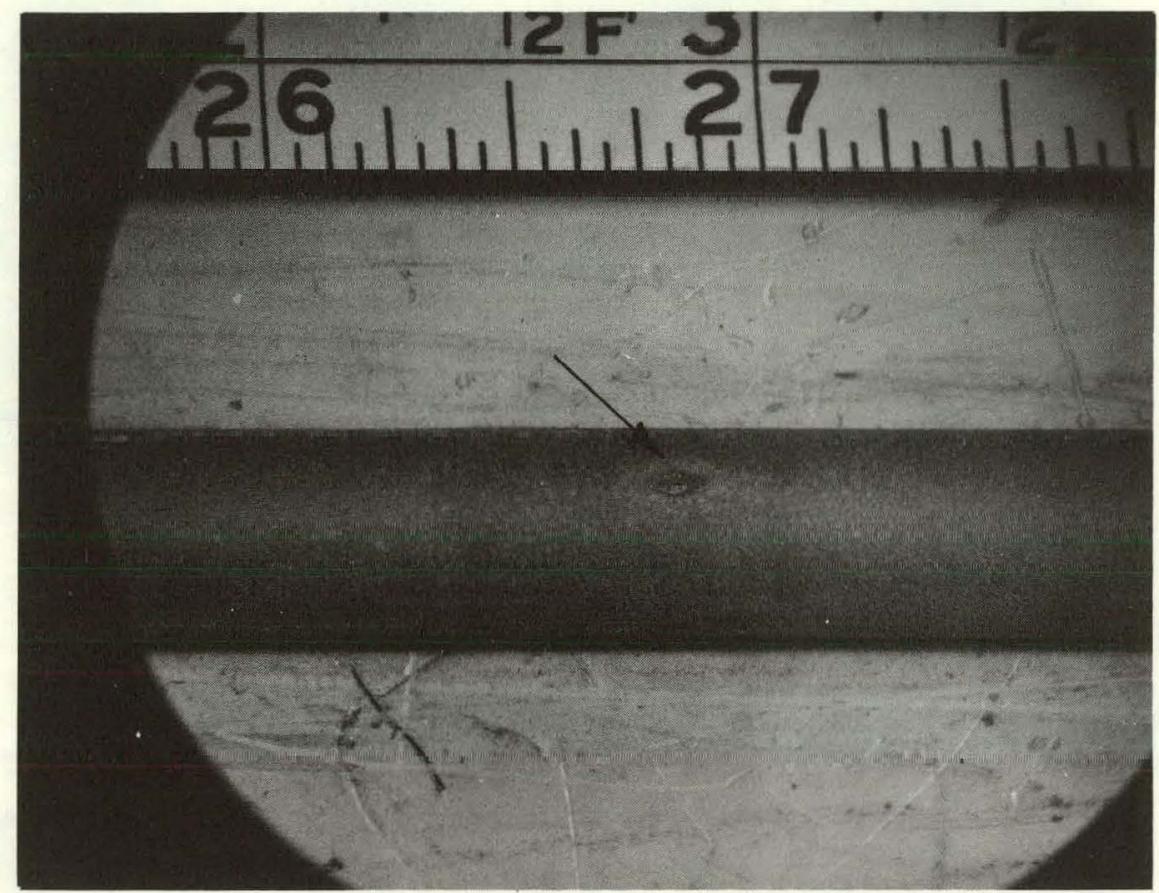

Figure 1. Subassembly Spacer Spring Marking on Rod 850 


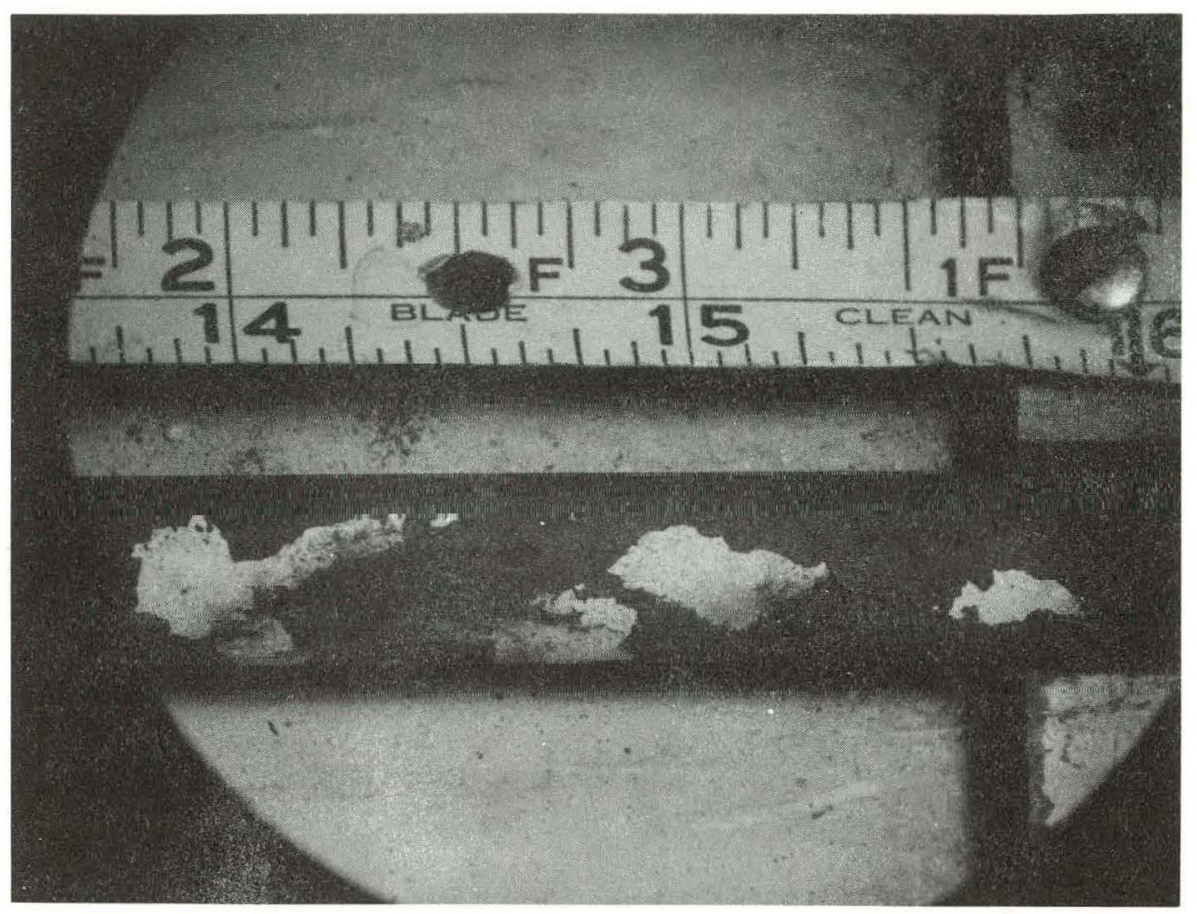

Figure 2. Region of Rod B56 Where Crud Has Spalled from Surface

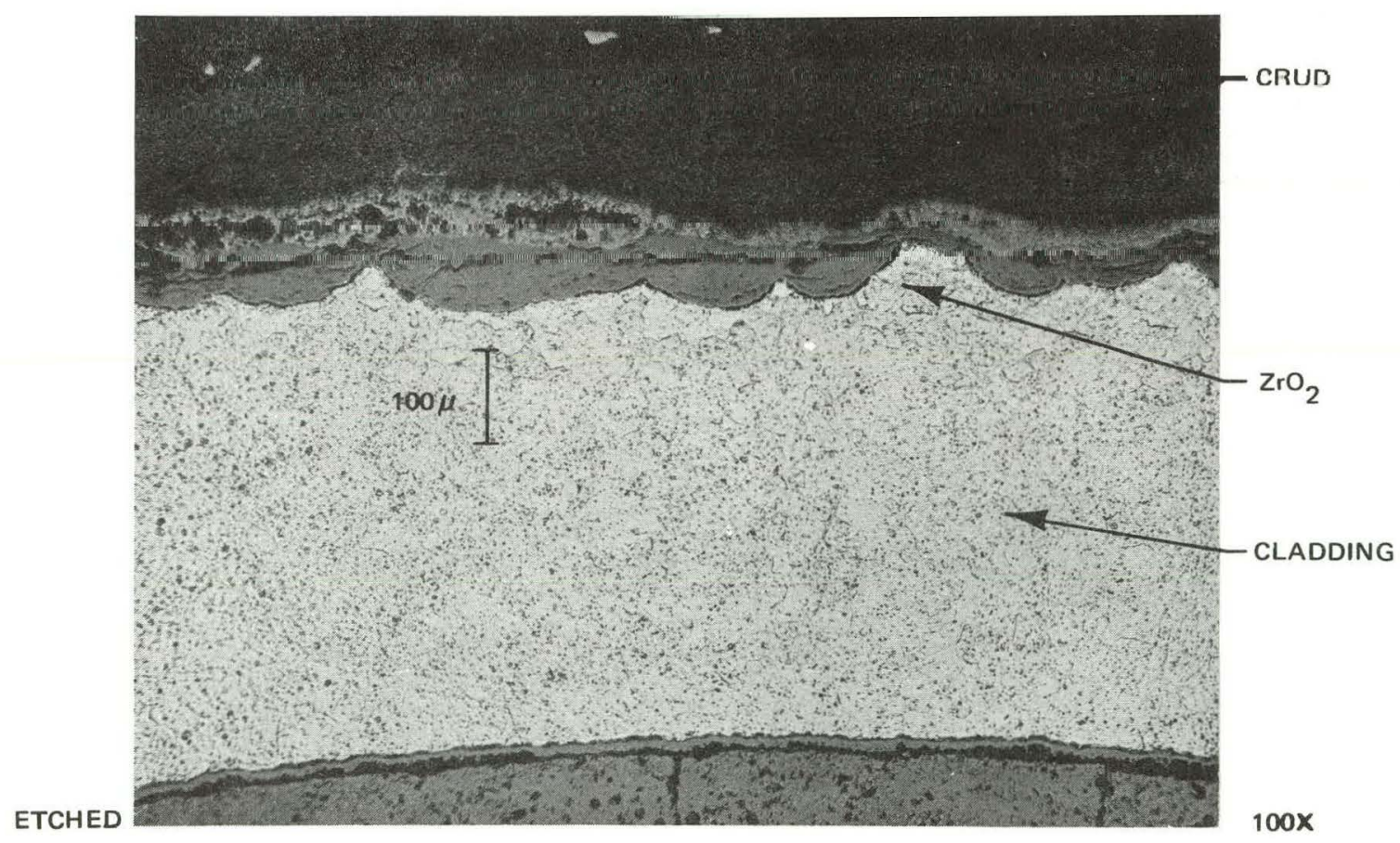

Figure 3. Portion of Rod B56 Cladding Showing Thick Crud and External $\mathrm{ZrO}_{2}$ (Specimen No. A624) 


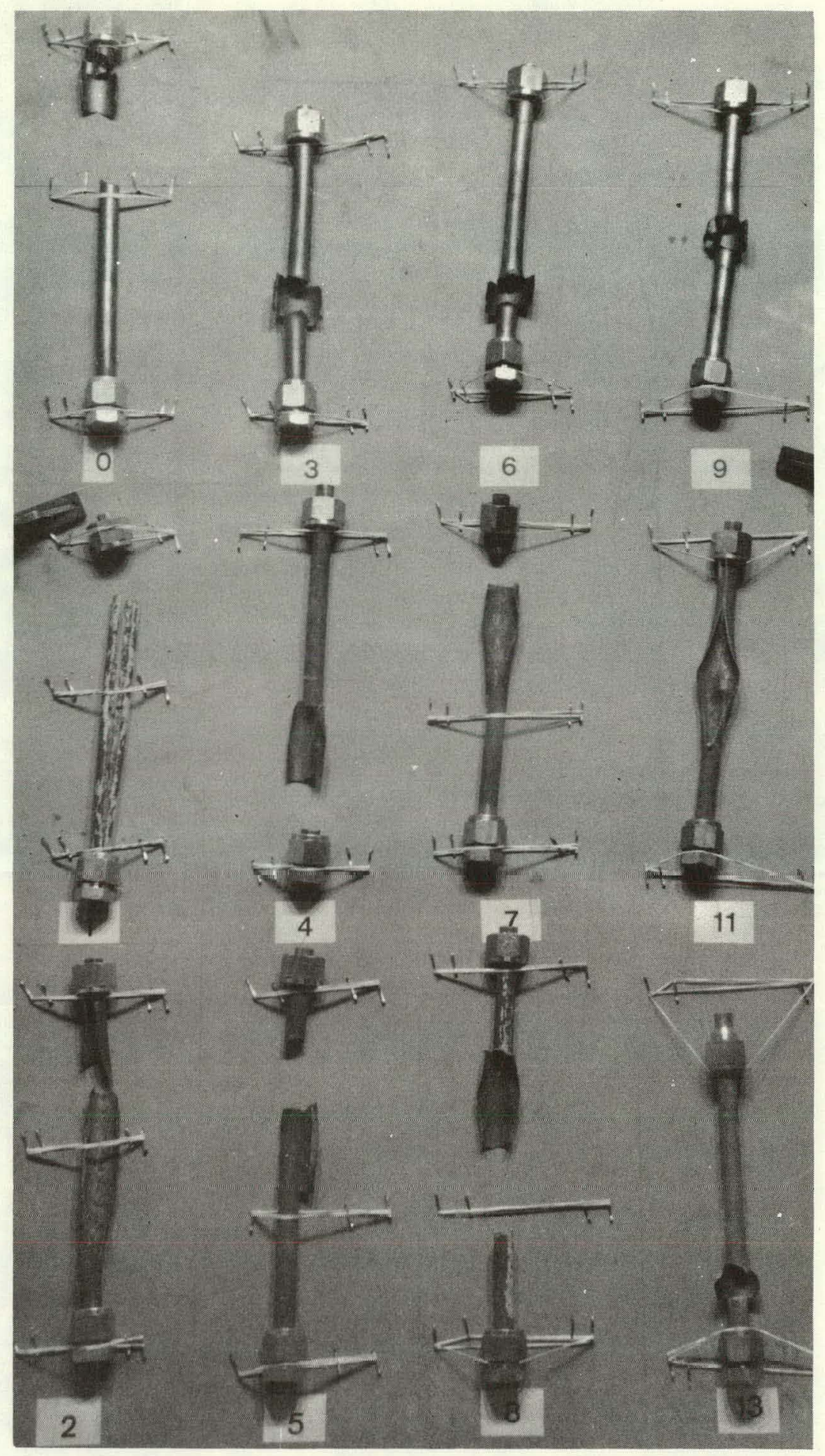

Figure 4. SA-1 Cladding Samples After Burst Testing (See Table 3 for key to sample designation) 


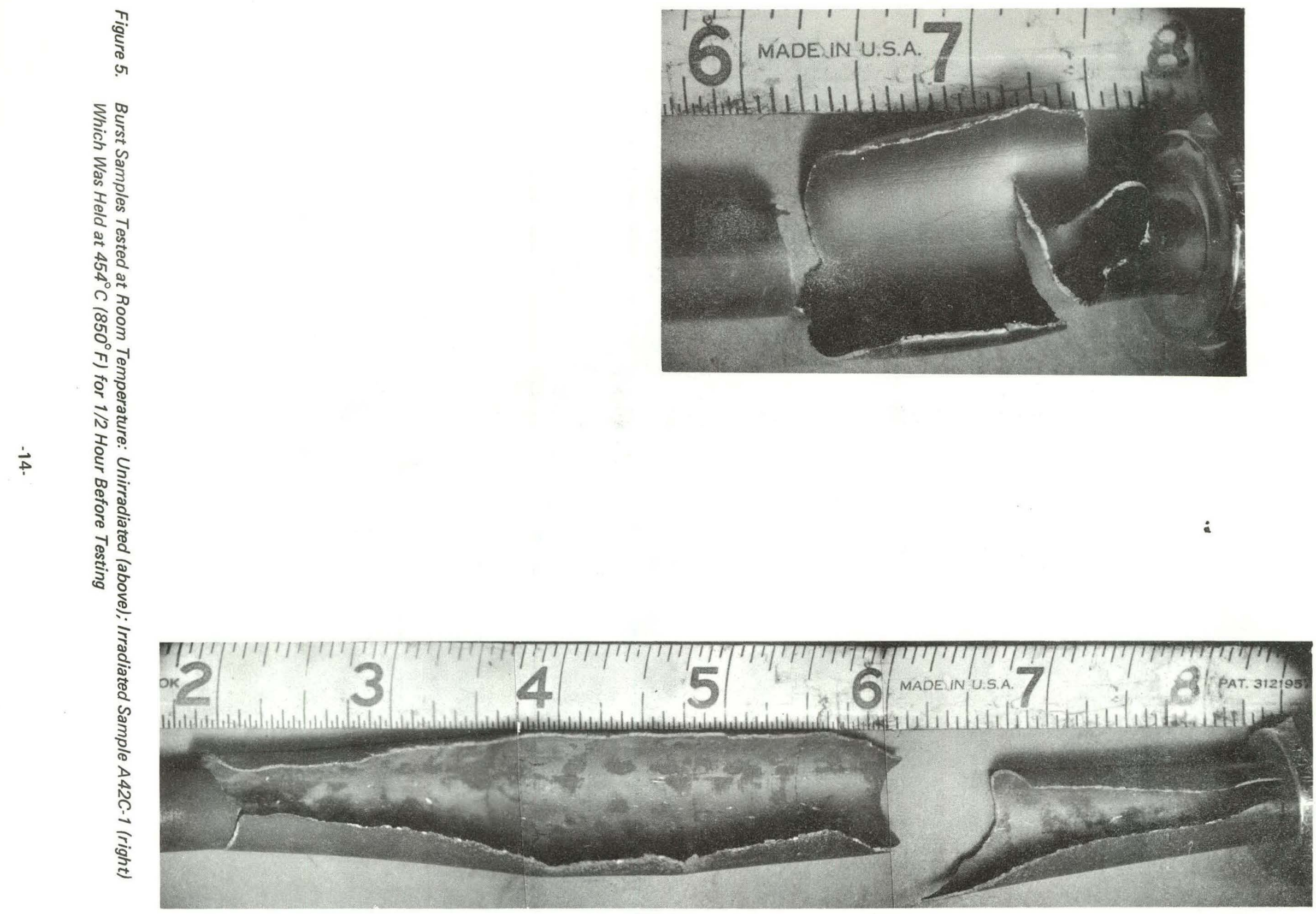



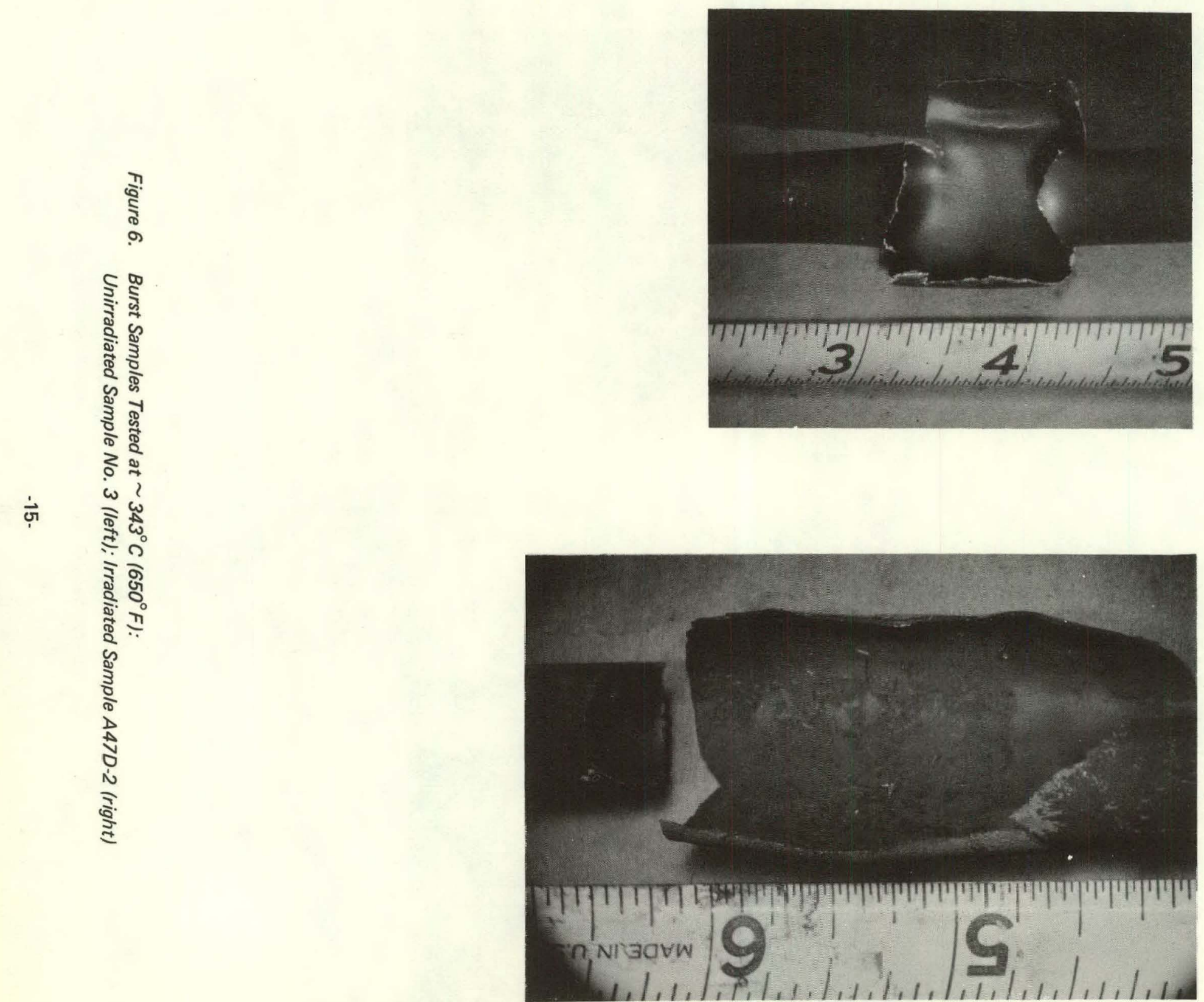

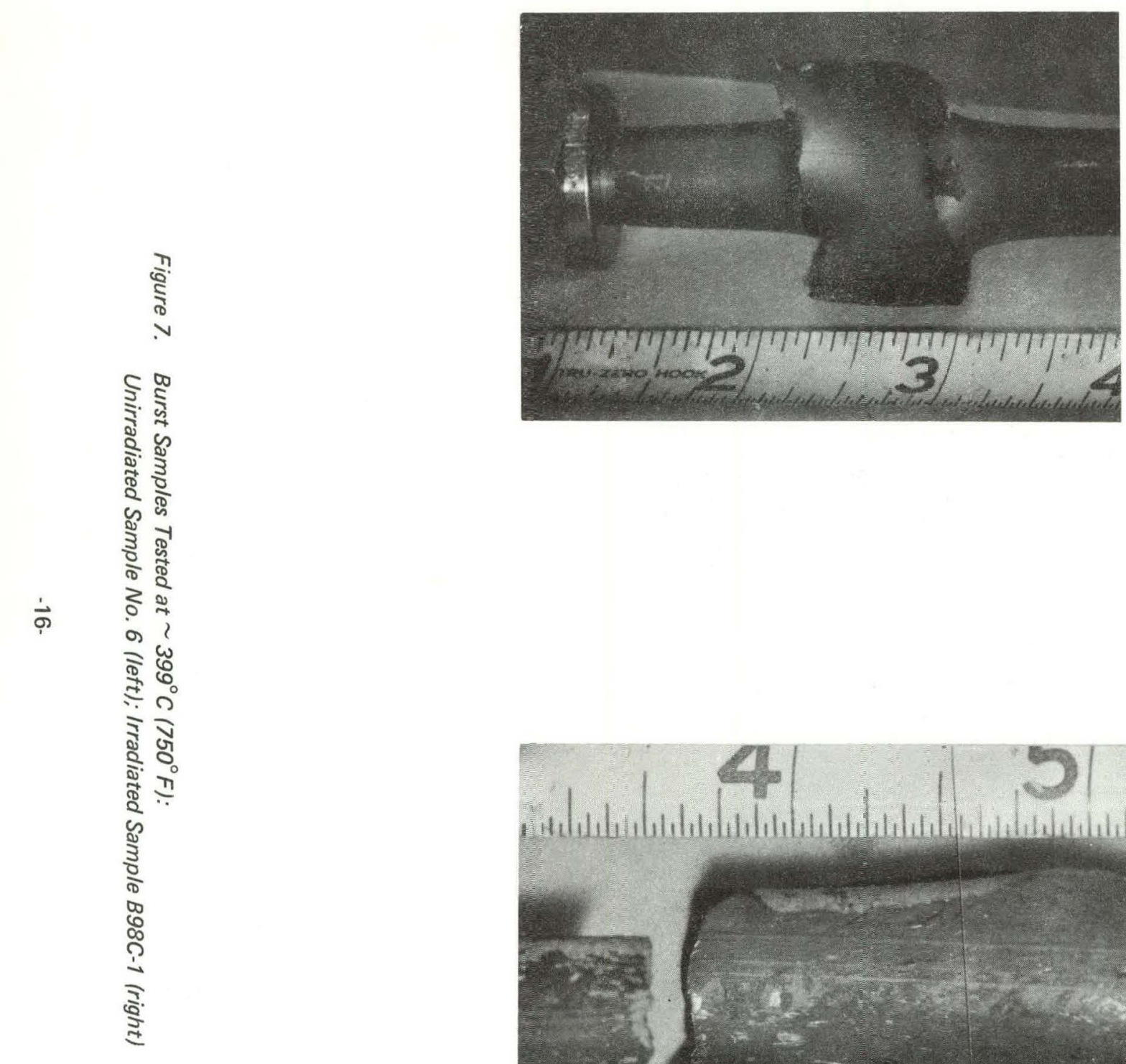

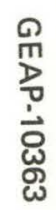

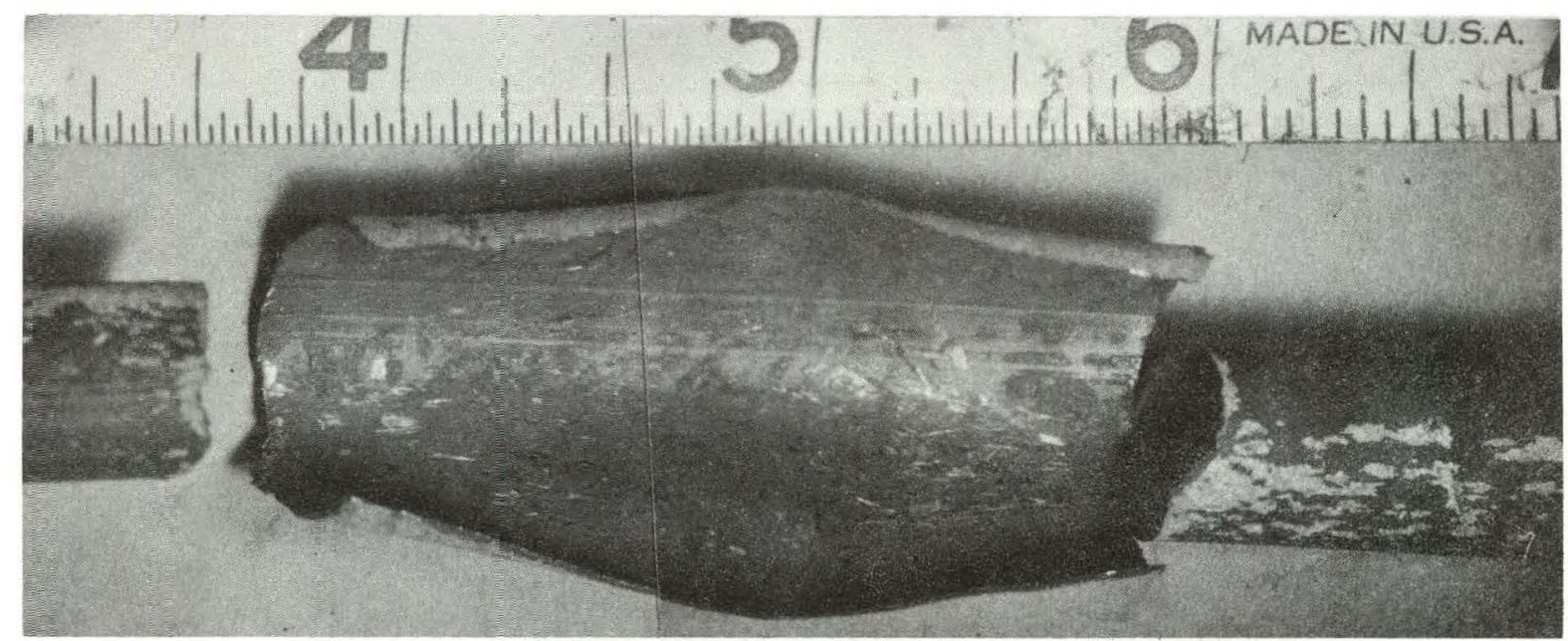




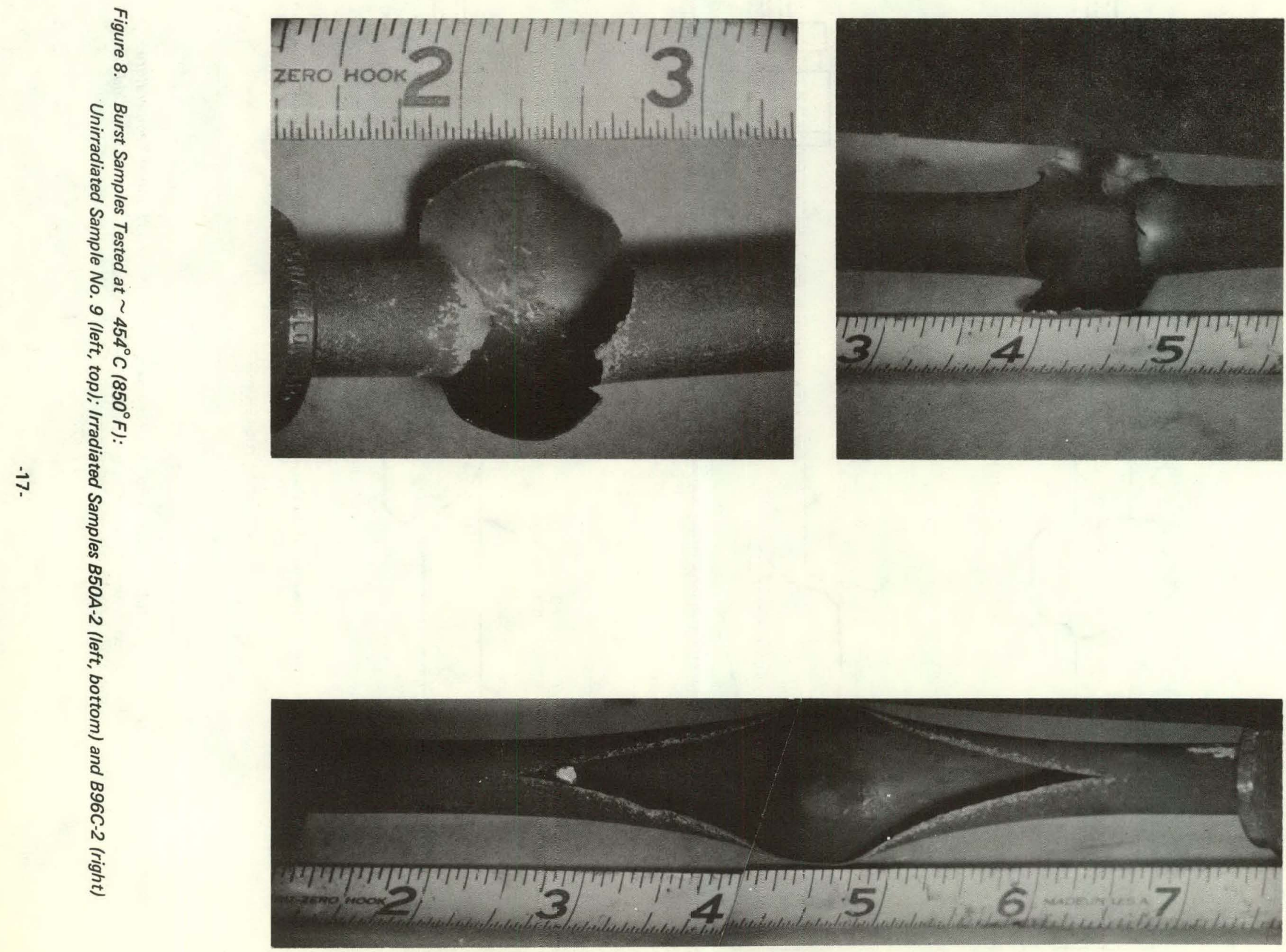


GEAP-10363

\begin{tabular}{l|llllllll}
0 & & & INCHES & & & 7 & 8 \\
\hline
\end{tabular}
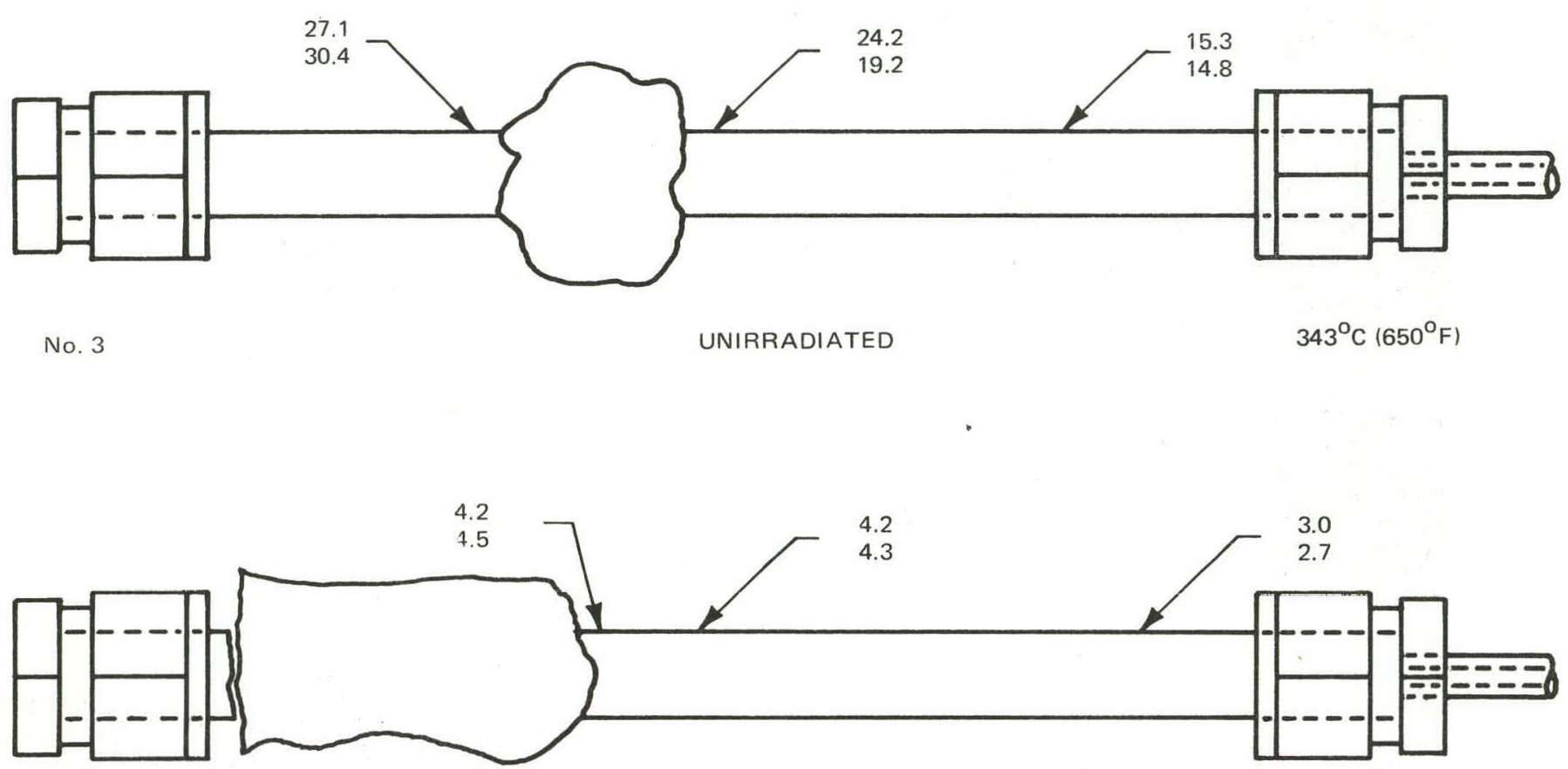

B96A-2

IRRADIATED

$348^{\circ} \mathrm{C}\left(659^{\circ} \mathrm{F}\right)$
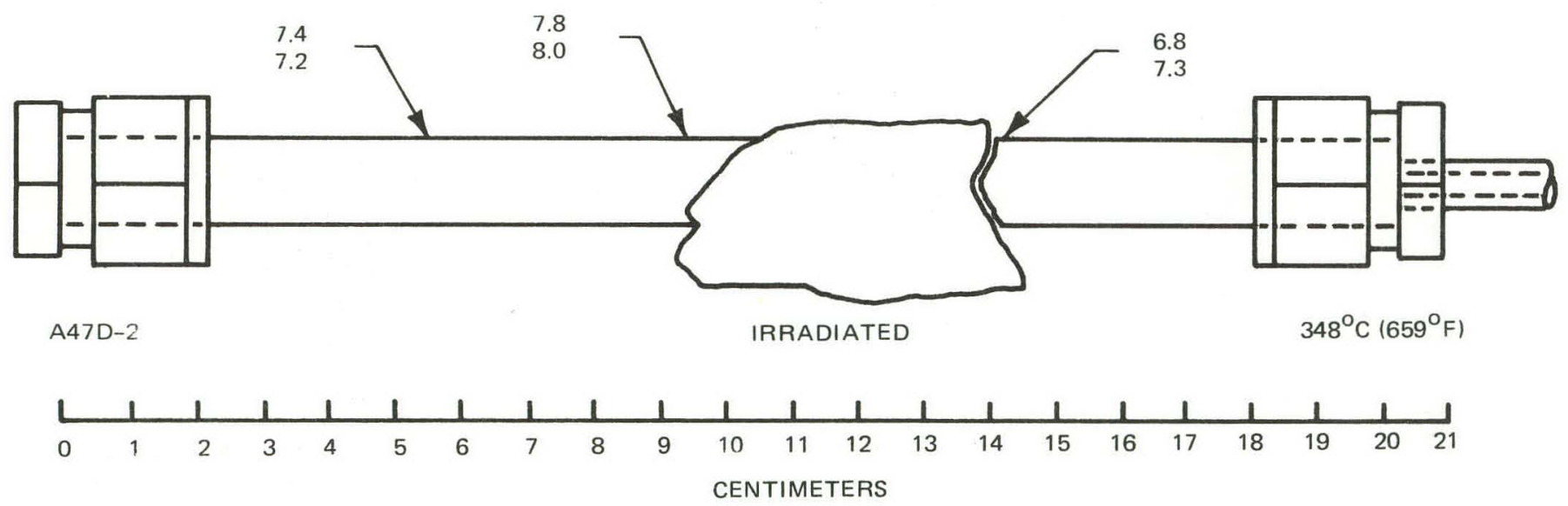

Figure 9. Values of $\left(D_{f}-D_{j}\right) / D_{i} \times 100$ at Various Points Along Samples Tested at a Nominal Temperature of $343^{\circ} \mathrm{C}\left(650^{\circ} \mathrm{F}\right)$. (Two determinations 90 degrees apart were made at each axial location indicated.) 

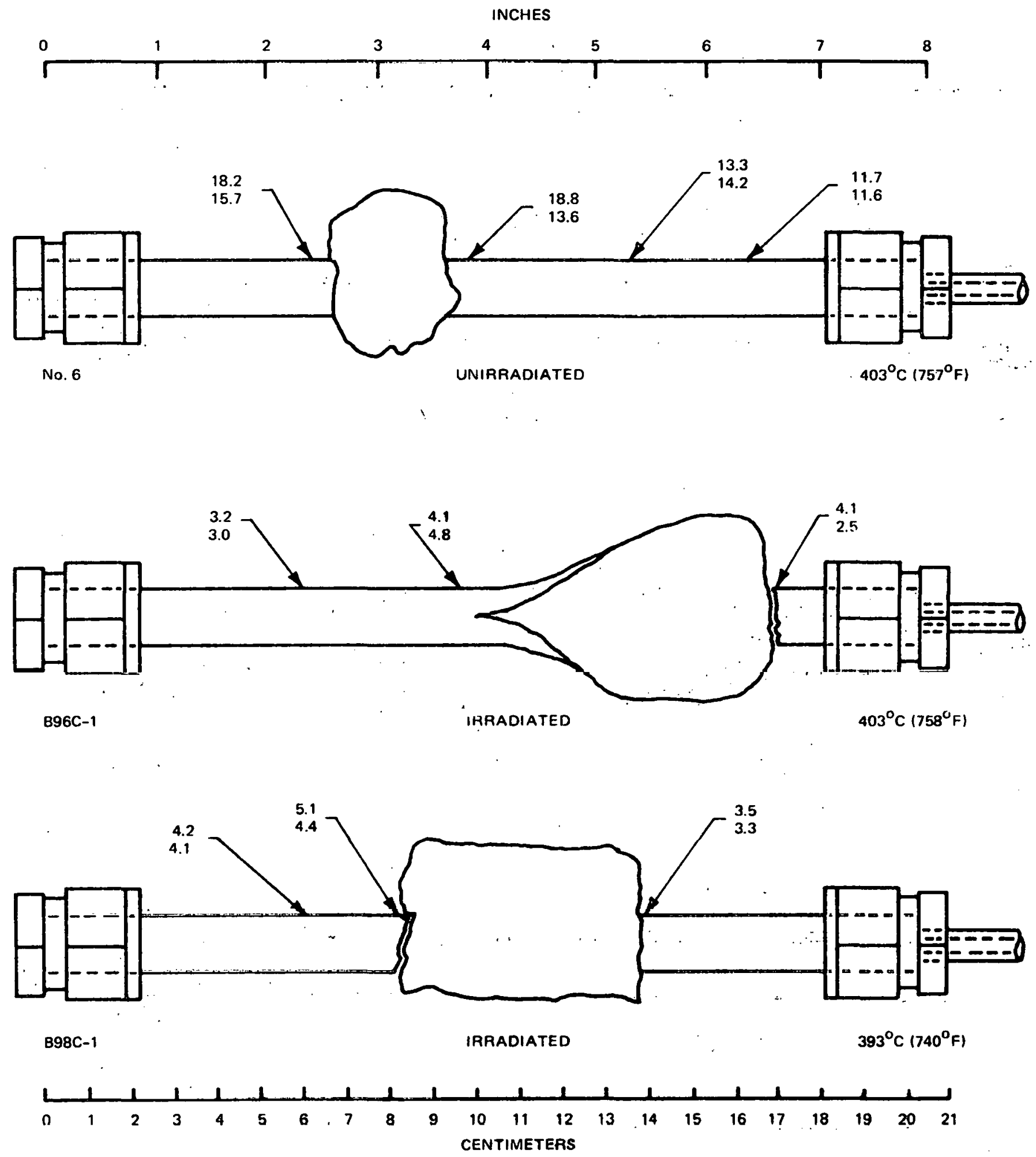

Figure 10. Values of $\left(D_{f}-D_{j}\right) / D_{i} \times 100$ at Various Points Along Samples Tested át a. Nominal Temperature of $399^{\circ} \mathrm{C}\left(750^{\circ} \mathrm{F}\right)$ 

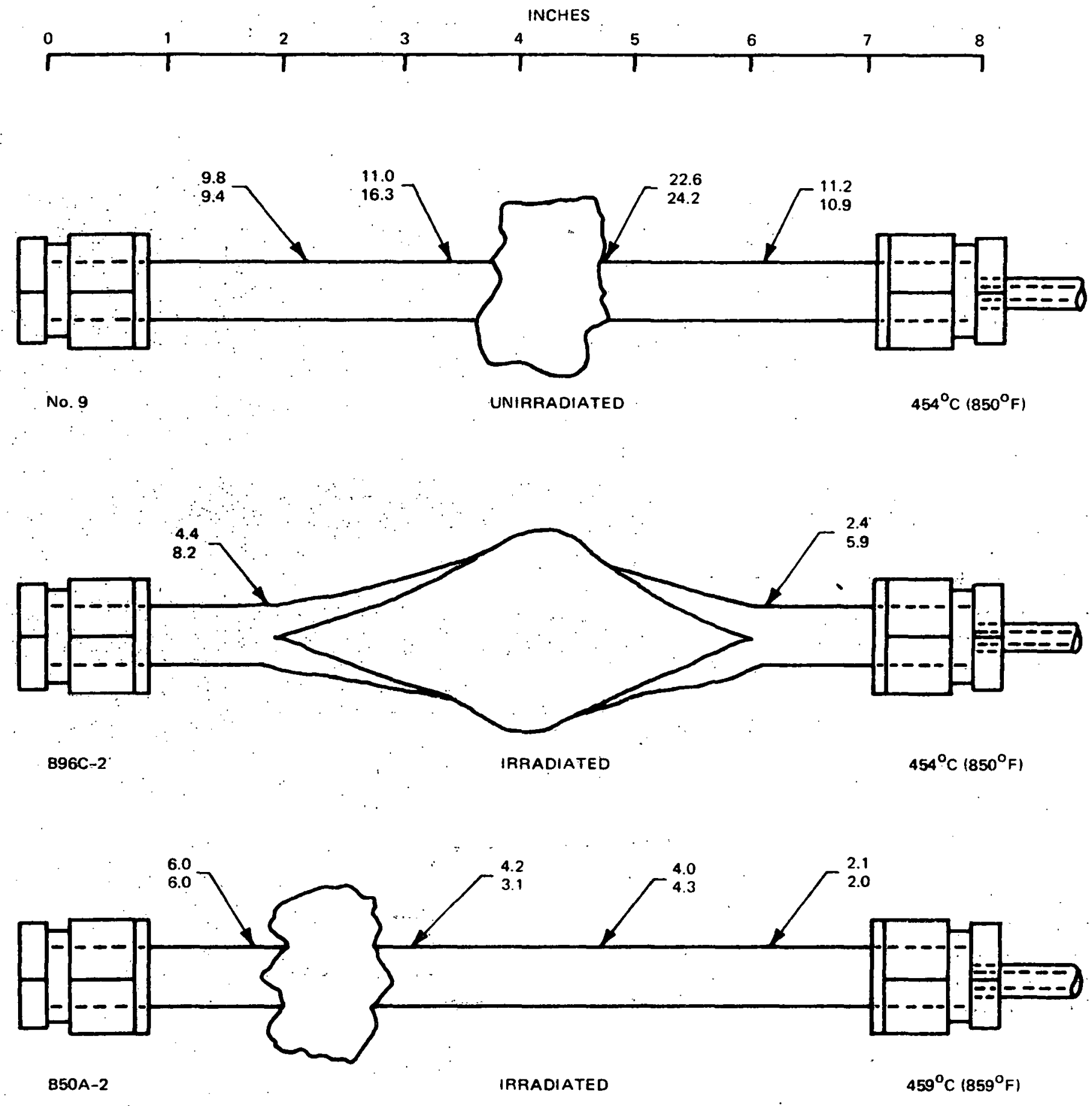

\begin{tabular}{|c|c|c|c|c|c|c|c|c|c|c|c|c|c|c|c|c|c|c|c|c|c|}
\hline$L$ & 1 & $\perp$ & $\perp$ & $L$ & 1 & 1 & 1 & $L$ & 1 & $\perp$ & 1 & 1 & $\mathcal{L}$ & 1 & 1 & 1 & 1 & 1 & 1 & 1 & $J$ \\
\hline 0 & 1 & 2 & 3 & 4 & 5 & 6 & 7 & 8 & 9 & 10 & 11 & 12 & 13 & 14 & 15 & 16 & 17 & 18 & 19 & 20 & 21 \\
\hline
\end{tabular}

Figure 11. Values of $\left(D_{f}-D_{j}\right) / D_{i} \times 100$ at Various Points. Along Samples Tested at a Nominal Temperature of $454^{\circ} \mathrm{C}\left(850^{\circ} \mathrm{F}\right)$ 


\section{4}

$29.4 \pm 5.1 \mathrm{~cm}(11.9 / 16 \pm 2 \mathrm{in.})$

TO TOP OF REACTOR ACTIVE FUEL ZONE

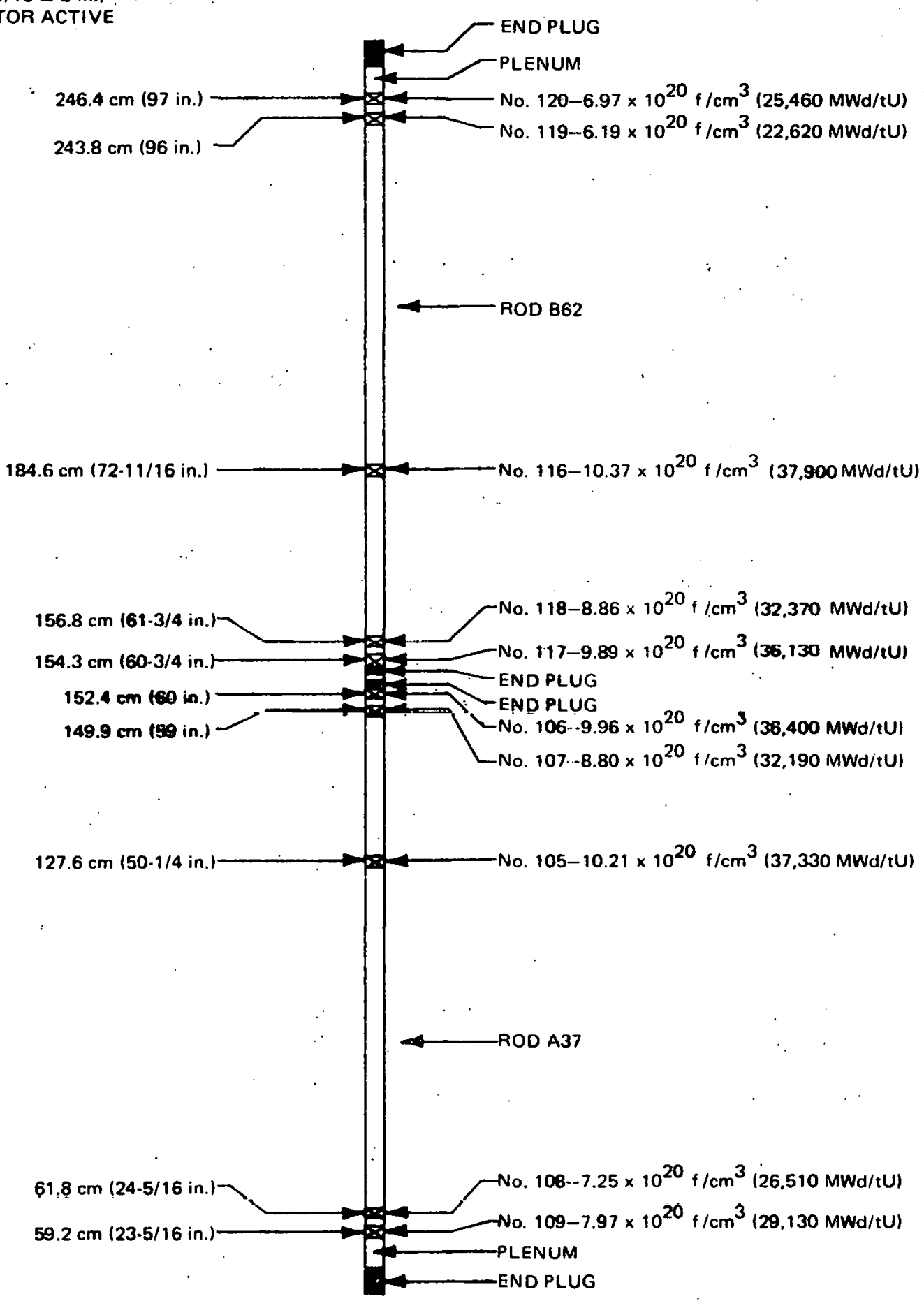

Figure 12. Locations of Burnup and Isotopic Composition Samples from Rods A37 and B62 in Terms of Distance from the Bottom of the Reactor Active Fuel Zone 


\section{REFERENCES}

1. Zircaloy-Clad $\mathrm{UO}_{2}$ Fuel Rod Evaluation Program, Quarterly Progress Report No. 12, August-October 1970, November 1970 (GEAP-10287).

2. Zircaloy-Clad $\mathrm{UO}_{2}$.Fuel Rod Evaluation Program, Quarterly Progress Report No. 10, February-April 1970, May 1970 (GEAP-10204).

3. Zircaloy-Clad $\mathrm{UO}_{2}$ Fuel Rod Evaluation Program, Quarterly Progress Report No. 11, May-July 1970, August 1970 (GEAP-10217).

4. Zircaloy-Clad. $\mathrm{UO}_{2}$ Fuel Rod Evaluation Program, Quarterly Progress Report No. 4, August 1968-October 1968, November 1968 (GEAP-5702).

5 Williamson, H. E., Baroch, C. J., Hoffmann, J. P., and Ikeuye, D. T., AEC Fuel Cycle Program-Examination of Zircaloy-Clad $\mathrm{UO}_{2}$ Fuel Rods Operated in the VBWR to 10,000 MWd/tU, March 15, 1965 (GEAP-4597).

\section{ACKNOWLEDGMENT}

The Zircaloy-Clad $\mathrm{UO}_{2}$ Fuel Rod Evaluation Program is sponsored by the Atomic Energy Commission, Division of Reactor Development and Technology, and is conducted by General Electric Company, with the following individuals contributing to the program during the report period:
G. P. Ferguson
R. E. Smith
IPO Materials Investigation
R.C. Douglas
D. L. Orton
IPO Remote Handling Operations
M. Vega
M. E. Carino
IPO Applications Engineering
C. P. Ruiz
NL Chemistry and Chemical Engineering Laboratory
J.P. Peterson
D. E. Rey
NL Analytical Chemistry
F. R. Smith.
M. M. Csicsery.
NL Ceramic Development
F. H. Megerth
RF\&RD Fuel Development-Water Reactors 


\section{DISTRIBUTION}

Atomic Energy Commission

San Francisco Operations Office

2111 Bancroft Way

Berkeley, California 94704

Arthur W. Larson

Site Representative

U.S. Atomic Energy Commission

c/o General Electric Company

310 DeGuigne Avenue

Sunnyvale, California 94086

U.S. Atomic Energy Commission Germantown, Maryland 20545

Attn: J.M. Simmons

U.S. Atomic Energy Commission

Germantown, Maryland 20545

Attn: A. Van Echo

U.S. Atomic Energy Commission

Germantown, Maryland 20545

Attn: J.A. Lieberman

U.S. Atomic Energy Commission Germantown, Maryland 20545

Attn: S.A. Szawlewicz

U.S. Atomic Energy Commission Germantown, Maryland 20545

Attn: M.A. Rosen

U.S. Atomic Energy Commission Germantown, Maryland 20545

Attn: E.E. Kintner

U.S. Atomic Energy Commission

Germantown, Maryland 20545

Attn: D.E. Erb

U.S. Atomic Energy Commission

Germantown, Maryland 20546

Attn: W.H. McVey

U.S. Atomic Energy Commission Germantown, Marvland 20545

Attn: I.F. Zartman

U.S. Atomic Energy Commission Germantown, Maryland 20545

Attn: J.W. Vaughan

U.S. Atomic Energy Commission

Germantown, Maryland 20545

Attn: Document Library

U.S. Atomic Energy Commission

Chicago Operations Office

9800 South Cass Avenue

Argonne, Illinois

Attn: M.E. Jackson, Senior Site Representative, ANL
$3 \quad$ U.S. Atomic Energy Commission

Oak Ridge Operations Office

Post Office Box E

Oak Ridge, Tennessee 37830

1

Attn: D.F. Cope, Senior Site Representative, ORNL

U.S. Atomic Energy Commission

Richland Operations Office

Richland, Washington

Attn: P.G. Holsted, Senior Site Representative, PNL

U.S. Atomic Energy Commission

2

Department of Technical Information Extension

Oak Ridge Operations Office

P.O. Box E

Oak Ridge, Tennessee $\mathbf{3 7 8 3 0}$

1 Attn: R.L. Shannon

U.S. Atomic Energy Commission

Savannah River Operations Office

1 P.O. Box 8

Aiken, South Carolina 29801

Attn: N. Stetson

1 Ames Laboratory

lowa State University

Box 1129 ISU Station

Ames, lowa $\mathbf{5 0 0 1 0}$

1 Attn: F.H. Spedding

Ames Laboratory

lowe State Univeraity

1 Box 1129 ISU Station

Ames, lowa 50010

Attn: O.N. Carlson

2 Ames Laboratory

lowa State University

Box 1129 ISU Station

Ames, lowa $\mathbf{5 0 0 1 0}$

1 Attn: W.L. Larsen

Argonne National Laboratory 9700 South Cass Avenue

1 Argonne, Illinois 60440

Attn: R.C. Vogel

Argonne National Laboratory

2 9700 South Cass Avenue Argonne, Illinois 60440

Attn: M.V. Nevitt

1 Argonne National Laboratory

9700 South Cass Avenue

Argonne, Illinois 60440

Attn: J.H. Kittel

Brookhaven National Laboratory

Upton, New York 11973

Attn: D.H. Gurinsky 
Los Alamos Scientific Laboratory P.O. Box 1663

Los Alamos, New Mexico 87544

Attn: D.E. Hall

Los Alamos Scientific Laboratory P.O. Box 1663

Los Alamos, New Mexico 87544

Attn: R.D. Baker

Oak Ridge National Laboratory

Oak Ridge Operations Office

P.O. Box E

Oak Ridge, Tennessee 37830

Attn: J.E. Cunningham

Oak Ridge National Laboratory

Oak Ridge Operations Office

P.O. Box E

Oak Ridge, Tennessee $\mathbf{3 7 8 3 0}$

Attn: P. Patriarca

Oak Ridge National Laboratory

Oak Ridge Operations Office

P.O. Box E

Oak Ridge, Tennessee 37830

Attn: D.E. Ferguson

Oak Ridge National Laboratory

Oak Ridge Operations Office

P.O. Box E

Oak Ridge, Tennessee 37830

Attn: J.R. Weir

Pacific Northwest Laboratory

P.O. Box 999

Richland, Washington 99352

Attn: F.W. Albaugh

Pacific Northwest Laboratory

P.O. Box 999

Richland, Washington 99352

Attn: J.J. Cadwell

Pacific Northwest Laboratory

P.O. Box 999

Richland, Washington 99352

Attn: A.L. Bement

Pacific Northwest Laboratory

P.O. Box 999

Richland, Washington 99352

Attn: E. Evans

Pacific Northwest Laboratory

P.O. Box 999

Richland, Washington 99352

Attn: R.L. Dillon

Pacific Northwest Laboratory

P.O. Box gyg

Hichlano. Wastuington 99352

Attn: R.G. Wheeler
1 Atomics International

P.O. Box 301

Canoga Park, California 91304

Attn: S. Carniglia

1 Atomics International'

P.O. Box 301

Canoga Park, California 91304

Attn: S. Arneson

2 Battelle Memorial Institute 505 King Avenue Columbus, Ohio 43201

Attn: S. Paprocki

Battelle Memorial Institute

1505 King Avenue

Columbus, Ohio 43201

Attn: D. Keller

Battelle Memorial Institute 505 King Avenue

Columbus, Ohio 43201

Attn: W. Berry

Battelle Memorial Institute

505 King Avenue

Columbus, Ohio 43201

Attn: DMIC

Babcock \& Wilcox Company

P.O. 'Box 1260

Lynchburg, Va. 24505

Attn: C. Baroch

Bobcock \& Wilcox Company

P.O. Box 1260

Lynchburg, Va. 24505

Attn: L. Weissert

Babcock \& Wilcox Company

P.O. Box 1260

1 Lynchburg, Va. 24505

Attn: J. Landis

Babcock \& Wilcox Company

P.O. Box 1260

1 Lynchburg, Va. 24505

Attn: C. Johnson

Combustion Engineering, Inc.

Naval Reactors Division

1 Windsor, Connecticut 06095

Attn: W.P. Chernock

Combustion Engineering, Inc. Naval Reactors Division

1 P.O. Box 400

Windsor, Connecticut 06095

Attn: S.S. Christopher

1 Gulf General Atomics, Inc.

P.O. Box 608

1

Attn: S. Jaye 
General Electric Company

KAPL

One River Road

Schenectady, N.Y.

Attn: A.E. Bibb

General Electric Company

NMPO

P.O. Box 132

Cincinnati, Ohio 45215

Attn: V.P. Calkins

General Electric Company

NMPO

P.O. Box 132

Cincinnati, Ohio 45215

Attn: C. Brassfield

General Electric Company

NMPO

P.O. Box 132

Cincinnati, Ohio 45215

Attn: J. McGurty

Savannah River Laboratory-du Pont E.I. du Pont de Nemours \& Co.

Savannah River Plant

Aiken. South Carolina 29801

Attn: TIS Document Room

Savannah River Laboratory du Pont E.I. du Pont de Nemours \& Co.

Savannah River Plant

Aiken, South Carulina 29801

Attn: R.R. Marshall

Westinghouse Electric Corporation

APD

P.O. Box 355

Pittsburgh, Pa. 15230

Attn: T. Stern
1 Westinghouse Electric Corporation

Bettis Atomic Power Plant

P.O. Box 79

West Mifflin, Pa. 15122

Attn: E.J. Kreigh

1

Westinghouse Electric Corporation Bettis Atomic Power Plant

P.O. Box 79

West Mifflin, Pa. 15122

1

Attn: R.H. Fillnow

Westinghouse Electric Corporation Bettis Atomic Power Plant

P.O. Box 79

West Mifflin, Pa. 15122

1 Attn: B. Lustman

Westinghouse Electric Corporation Bettis Atomic Power Plant

$1 \quad$ P.O. Box 79

West Mifflin, Pa. 15122

Attn: W. J. Babyak

Idaho Nuclear Corporation

P.O. Box 1845

1 Idaho Falts, Idaho 83401

Attn: J.M. Beeston

Idaho Nuclear Corporation

P.O. Box 1845

Idaho Falls, Idaho 83401

Attn: W. C. Francis

2

United Nuclear Library
Grasslands Road

Elmsford, New York 10523 